Results of Crossing two Hemipterous Species, with reference to the Inheritance of two Exclusively Male Characters. By Katharine Foot and E. C. Strobell. (Communicated by Prof. E. B. Poulton, F.R.S., Pres.L.S.)

\title{
(Plates 41-47.)
}

\section{[Read 3rd June, 1915.]}

THE results given in this paper are due to the interesting discovery made by Dr. Eltringham of Oxford, that there is a marked difference in the length of the intromittent organ of the two hemipterous species Euschistus variolarius and Euschistus servus.

We feel greatly indebted to Professor Poulton for kindly suggesting Dr. Eltringham to us, in response to our expressed wish to find an experienced entomologist in England who would be willing to study $E$. variolarius and E. servus with a view of discovering some marked character distinctive of each species that could be profitably studied in the hybrids.

The result of Dr. Eltringham's investigations is of special satisfaction to us, because the discovery of a difference in the length of the intromittent organ of the two species offers a valuable control for the results obtained and the conclusions we were able to draw from our study of the transmission of the genital spot*, enabling us to compare the inheritance of these two exclusively male characters in the same insect.

During our experimental work on the genital spot (Foot and Strobell, '13 \& '14) we carefully isolated and preserved each insect, in the hope that future investigation by an experienced entomologist might reveal some other marked character in these insects that would enable us to determine what relation, if any, might exist between the inheritance of a second definite character and the inheritance of the genital spot in each hybrid.

Having our material preserved in this way has made it possible for us to. demonstrate both the exact appearance of the genital spot and the exact length of the intromittent organ in one and the same individual of the $\mathrm{F}_{1}$ and $\mathrm{F}_{2}$ hybrids, and also of the offspring from the backcross. We have madethis comparison very simple by placing the photographs of the intromittent organs demonstrated in this paper in exactly the same order in which the photographs of the insects themselves were placed in our paper on the

* T'his is a distinct black spot which is present on the genital segment of the males of Euschistus variolarius, and is a distinguishing feature of this species, while it is absent in $E$. servus. It is the presence of this exclusively male character which led us to cross these two species, with the hope of putting to an experimental test the chromosome-theory of sex-determination (Foot and Strobell, '13 \& '14).

LINN. JOURN.-ZOOLOGY, VOL. XXXII. 
inheritance of the genital spot, which is published in this same volume (Plates 28-34). It is only necessary to compare the two sets of photographs in order to determine whether any definite relation exists in the inheritance of these two exclusively male characters. Such a comparison proves conclusively that the two are not linked in inheritance (see Linkage, p. 475).

The study of the genital spot in these hybrids (Foot and Strobell, '13 \& '14) forced certain conclusions as to its hearing on recent chromosometheories of heredity, and also its bearing on Mendel's law of heredity. We shall demonstrate in the following paper that the results obtained from the study of the genital spot are in fact duplicated in the case of the intromittent organ-the study of this second exclusively male character supporting in every detail the conclusions forced by the facts of inheritance of the genital spot.

\section{Results and Discussion.}

We have dissected the intromittent organs from the genital segment of many of the parent species and from all the hybrids both of the $\mathrm{F}_{1}$ and $\mathrm{F}_{2}$ generations, and also from the offspring of the backcross. After mounting, the intromittent organs were photographed at a magnification of 20 diameters, and all the measurements were carefully made from these photographs; therefore all the recorded lengths of the intromittent organs must be reduced to one-twentieth to obtain the actual lengths.

The intromittent organ of Euschistus variolarius (at a magnification of 20 diameters) varies in length between $85.5 \mathrm{~mm}$. and $106 \mathrm{~mm}$., while that of Euschistus servus varies between $146 \mathrm{~mm}$. and $182 \mathrm{~mm}$. These measurements were made from 62 pure variolarius specimens, and from 62 pure servus specimens.

The following tables give the measurements of the photographs of the intromittent organs (arranged in order of length) of the parent species, of hybrids, and of the backcross.

Table 1 gives the lengths of the intromittent organs from 62 specimens of Euschistus variolarius, and shows those cases in which 2 or more specimens have the same length.

Table 2 gives the lengths of the 62 intromittent organs from Euschistus servus.

Tables 3 to 11 show the lengths of the intromittent organs from all the $\mathrm{F}_{2}$ hybrids and from the offspring of the backcross. These tables also show to what degree the genital spot is inherited by each hybrid, and they therefore demonstrate what relation, if any, exists in the inheritance of these two exclusively male characters. Tables 3 to 9 inclusive give the lengths of the intromittent organs for each family of the 7 pairs of $F_{1}$ hybrids ; and the mean length of the intromittent organ is computed for each separate family as well as for the total number of $\mathrm{F}_{2}$ hybrids. 


\section{Table 1.}

Lengths of intromittent organs from 62 specimens of Euschistus variolarius. $\times 20$ diams.

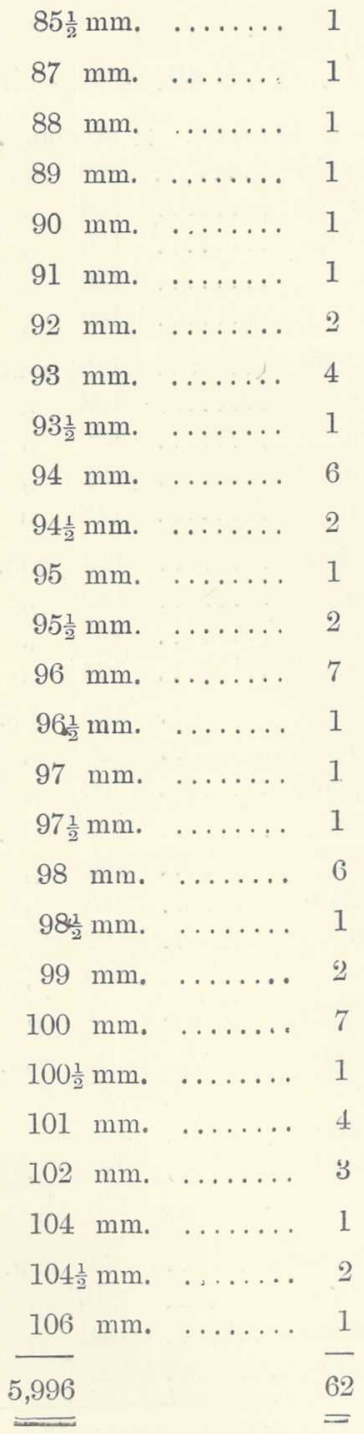

Mean length $=96.70 \mathrm{~mm}$.

\section{Table 2.}

Lengths of intromittent organs from 62 specimens of Euschistus servus. $\times 20$ diams.

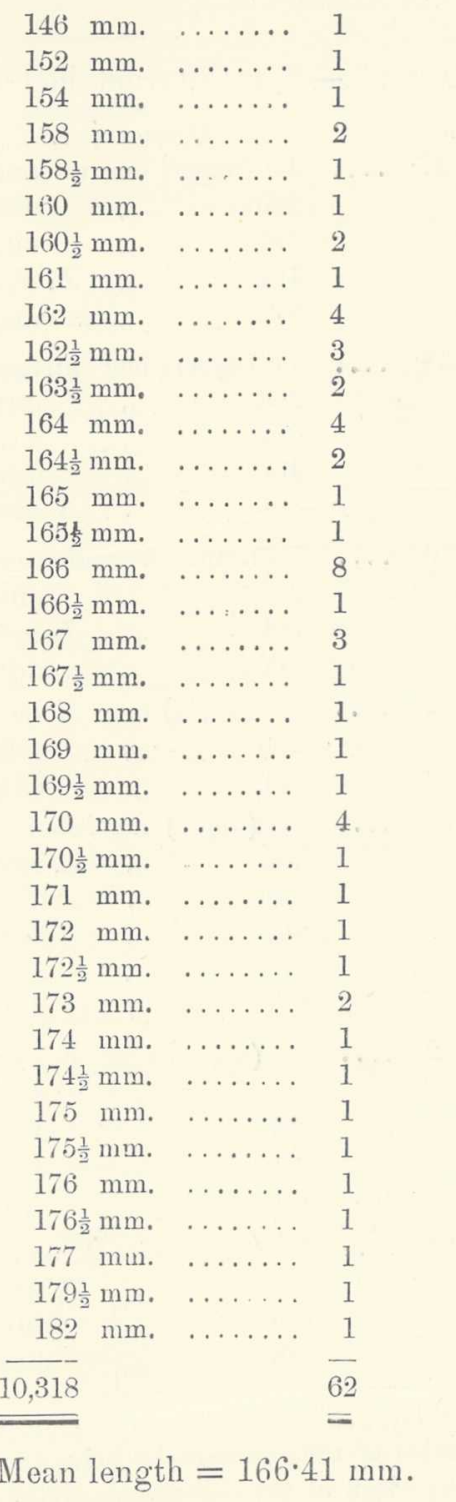




\section{TABles 3 To 10.}

Lengths of the intromittent organs in the $\mathrm{F}_{2}$ hybrids, showing the influenceof the two original parent species, and a comparison of these lengths with the inheritance of the E. variolarius genital spot. This comparison"demonstrates that these two exclusively male characters are not linked in inheritance.

TABLe 3.- $\mathrm{F}_{2}$ males from the 1 st pair of $\mathrm{F}_{1}$ hybrids. Plate 42. 43 specimens.

Photos.

Genital spot.*

$17 \ldots$ 1st (upper) bug intermediate.

2nd $"$ ditto.

3rd " ditto.

4th $\quad$ the servus.

5th " intermediate.

18 .... 1st (upper) bug intermediate.

2nd $"$ ditto.

3rd " ditto.

4 th,$"$ ditto.

5th $\quad$ E. servus.

19 .... 1st (upper) bug intermediate. and , ditto.

3rd $\quad$ E. servus.

4th " ditto.

20 ... 1st (upper) bug E. servus.

2nd $\quad, \quad$ ditto.

3rd $"$ ditto.

21 .... lst (upper) bug intermediate.

2nd,$\quad$ E. servus.

3rd " , ditto.

4 th $"$ ditto.

5th $\quad, \quad$ ditto.

6 th $\quad$ ditto.

22 ... 1st (upper) bug E. servus.

2nd , ditto.

3rd $"$ ditto.

4th , ditto.

5th $\quad, \quad$ ditto.

23 ... 1st (upper) bug E. variolarius.

2ad " E. servus.

3rd " ditto.

4th $"$, ditto.
Intromittent organ. $\times 20$ diams.

E. variolarius ....... $96 \mathrm{~mm}$.

E. servus $\quad \ldots \ldots \ldots .146 \quad "$

Intermediate ...... 130 "

ditto $\ldots \ldots \ldots 136$,

E. servus $\quad \ldots \ldots \ldots .150$,

Intermediate ....... $112 \frac{1}{2} \mathrm{~mm}$.

ditto $\ldots \ldots \ldots 128$,

ditto $\ldots \ldots \ldots .122$,

ditto ...... 137 ,

E. servus $\quad \ldots \ldots \ldots, 148$ ",

Intermediate ....... $114 \mathrm{~mm}$.

ditto $\ldots \ldots \ldots 129$,

ditto $\ldots \ldots . .139 \frac{1}{2}$,

ditto $\ldots \ldots \ldots, 144$,

Intermediate ...... $130 \mathrm{~mm}$.

ditto ....... 120 ,

E. variolarius $\ldots \ldots \ldots .98 \quad 98$

Intermediate ....... $124 \mathrm{~mm}$.

E. servus $\quad \ldots \ldots \ldots .152$ "

Intermediate ....... 133 "

ditto $\ldots \ldots \ldots .122$,

ditto ........ 136 ,

E. variolarius $\ldots \ldots \ldots .97$,

Intermediate ...... $136 \mathrm{~mm}$.

E. servus $\quad \ldots \ldots \ldots .146$ "

Intermediate ....... 124 "

ditto $\ldots \ldots \ldots 128 \frac{1}{2}$,

ditto $\quad \cdots \ldots$. 130 ,

E. variolarius ...... $98 \mathrm{~mm}$.

Intermediate $\ldots \ldots \ldots, 120$,

E. variolarius ........ 104,

Intermediate $\ldots \ldots \ldots, 122$,

* The genital serment of these insects is demonstrated in Plates 28-34 of this volume, the number of the photographs being the same for the two papers, thus admitting an accurate comparison of the inheritance of the genital spot and the type of intromittent organ. In classifying the photographs of these hybrids we included under the serrus type not only those specimens with no spot whatever, but also those with merely a faint indication of a spot, for the latter was not visible in the living stecimens nor in those freshly killed. Such a faint indication of a spot will probably not show in all the prints. 
Photos.

24 ... 1st (upper) bug intermediate. 2nd,$\quad$ E. servus. 3rd " ditto.

25 .... 1st (upper) bug intermediate.

$\begin{array}{llc}\text { 2nd } & " & \text { ditto. } \\ \text { 3rd } & " & \text { ditto. } \\ \text { 4th } & , & \text { ditto. } \\ \text { 5th } & " & \text { ditto. } \\ \text { 6th } & " & \text { E. servus. } \\ \text { 7th } & " & \text { ditto. } \\ \text { 8th } & , & \text { ditto. }\end{array}$

Intromittent organ. $\times 20$ diams. E. variolarius ....... $100 \mathrm{~mm}$. Intermediate $\ldots \ldots \ldots, 114$, ditto $\quad \ldots \ldots .132 \frac{1}{2}$,

Intermediate $\ldots \ldots \ldots \quad 114 \frac{1}{2} \mathrm{~mm}$. ditto ....... 123

E. variolarius $\ldots \ldots \ldots, 100$,

Intermediate $\ldots \ldots \ldots, 108$,

E. variolarius $\ldots \ldots \ldots . . .63$,

Intermediate $\ldots \ldots \ldots, 132$,

E. variolarius $\ldots \ldots \ldots$.... $85 \frac{1}{2}$,

Intermediate $\ldots \ldots, 140$,

Mean length of intromittent organ, $123.14 \mathrm{~mm}$.

TABLE 4.- $\mathrm{F}_{2}$ males from the second pair of $\mathrm{F}_{1}$ hybrids. Plate 43. 30 specimens.

Photos.

$26 \quad \ldots \quad$ 1st (upper) bug $E$. variolarius. 2nd ..., intermediate.

3rd ..... , ditto.

4th $"$ ditto.

5th " ditto.

27 .... 1st (upper) bug intermediate. 2nd $\cdots \quad$ E. servus.

3rd "... ditto.

4th " ditto.

28 ... 1st (upper) bug E. variolarius. 2nd " intermediate.

3rd , E. servus.

4th , ditto.

5th ..., intermediate.

6th " E. servus.

29 ... 1st (upper) bug E. servus.

2nd $"$ ditto.

3rd " ditto.

4th , intermediate.

5th .. " E. servus.

30 ... 1st (upper) bug E. servus.

2nd ditto.

3rd $"$ ditto.

4 th .. ditto.

$31 \quad \ldots \quad$ 1st (upper) bug intermediate.

2nd $"$ ditto.

3rd .. " ditto.

$32 \quad \ldots$ 1st (upper) bug $E$. variolarius.

2nd $\ldots$ intermediate.

3rd
Intromittent organ. $\times 20$ diams.

Intermediate ....... $115 \frac{1}{2} \mathrm{~mm}$.

E. variolarius ....... 100 ,

Intermediate ....... 116 ,

ditto $\ldots \ldots \ldots, 118$,

ditto ....... 118 ,

E. variolarius ...... $99 \mathrm{~mm}$.

Intermediate ....... 130 ,

ditto $\ldots \ldots \ldots 130$,

ditto ....... 130,

E. variolarius $\quad \ldots \ldots \ldots \quad 90 \mathrm{~mm}$.

Intermediate ....... 142 ,

ditto ....... 124 ,

ditto $\ldots \ldots .131$,

ditto ...... 121 ,

ditto $\ldots \ldots \ldots \quad 127 \frac{1}{2}$,

Intermediate . ..... $124 \mathrm{~mm}$.

ditto ...: .. 123 ,

ditto $\ldots \ldots \ldots$ 125,

ditto $\ldots \ldots \ldots 126$,

ditto $\ldots \ldots \ldots 126$,

Intermediate $\ldots \ldots \ldots .130 \mathrm{~mm}$.

ditto $\ldots \ldots \ldots 134 \frac{1}{2}$,

ditto $\ldots \ldots \ldots$ ' $115 \frac{1}{2}$,

ditto $\ldots \ldots \ldots 133$,

Intermediate ...... $114 \mathrm{~mm}$.

ditto ....... 114,

E. variolarius $\ldots \ldots \ldots \quad 99 \frac{1}{2}$,

Intermediate ....... $114 \frac{1}{2} \mathrm{~mm}$.

ditto $\ldots \ldots \ldots, 122$,

ditto ....... 127 ,

Mean length of intromittent organ, $120.67 \mathrm{~mm}$. 
TABLE 5.- $-\mathrm{F}_{2}$ males from the third pair of $\mathrm{F}_{1}$ hybrids. Plate 44 . 48 specimens.

Photos.

Genital spot.

33 .... 1st (upper) bug intermediate.

$\begin{array}{lll}\text { 2nd } & \text { ditto. } \\ \text { 3rd } & \text { ditto. } \\ \text { 4th } & " & \text { ditto. }\end{array}$

4th ditto.

5th ....... , E. servus.

6 th ....., intermediate.

34 "... 1st (upper) bug E. variolarius. 2nd " intermediate.

3rd … " ditto.

4th $\quad$ th $\quad$ E. servus.

5th " $\quad$ E. variolarius.

6th $\quad$ ditto.

7 th $\quad "$ intermediate,

8 th " $"$ ditto.

$35 \quad \ldots$ 1st (upper) bug $E$. variolarius.

2nd,$\quad$ ditto.

3rd " intermediate.

4th $"$, ditto.

5th $\quad \# \quad E$. servus.

$36 \quad \ldots$. 1st (upper) bug $E$. variolarius. 2nd, intermediate.

3rd " $"$ ditto.

4th " $\quad$ E. servus.

5th … ditto.

6th ditto.

7th $"$ ditto.

$37 \quad \ldots \quad$ 1st (upper) bug E. servus. 2nd $"$ intermediate. 3rd " E. servus.

38 ... 1st (upper) bug intermediate. 2nd,$\quad$ ditto. 3rd " ditto. 4th $\quad$ E. servus. 5th " $"$ ditto.

$39 \quad \ldots \quad$ 1st (upper) bug intermediate. 2nd $"$ ditto. 3rd " $\quad$ E. servus. 4 th $\quad "$ ditto.

40 ... 1st (upper) bug E. variolarius. 2nd, intermediate.

3rd,$\quad$ ditto.

4th,$"$ ditto.

5 th . , ditto.

6th $"$, ditto.

7th $"$ ditto.

41 ... 1st (upper) bug E. variolarius.

2nd " intermediate.

3rd ditto.
Intromittent organ. $\times 20$ diams.

Intermediate ...... $117 \frac{1}{2} \mathrm{~mm}$.

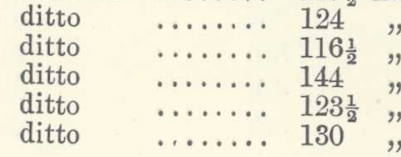

Intermediate $\ldots \ldots \ldots, 128 \mathrm{~mm}$.

ditto $\ldots \ldots \ldots, 131$,

ditto $\ldots \ldots \ldots, 140$,

ditto $\ldots \ldots \ldots .130$,

ditto $\ldots \ldots \ldots, 140$,

ditto $\ldots \ldots \ldots, 121 "$

ditto $\quad \ldots \ldots \ldots, 123$,"

E. servus $\quad$....... $147 \quad$

E. variolarius $\quad \ldots \ldots \ldots .104 \mathrm{~mm}$.

Intermediate $\ldots \ldots \ldots, 115$,

ditto $\quad \ldots \ldots \ldots, 126$,

ditto $\ldots \ldots \ldots, 134$,

ditto $\ldots \ldots \ldots$ 134 $\frac{1}{2}$,

Intermediate ...... $114 \mathrm{~mm}$.

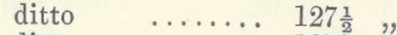

ditto $\quad \ldots \ldots \ldots 127 \frac{1}{2}$

ditto $\quad \ldots \ldots \ldots$. 124 ,

ditto $\quad \ldots \ldots \ldots, 142$,

ditto $\ldots \ldots \ldots 120$,

ditto $\quad \ldots \ldots .127 \frac{1}{2}$,

Intermediate $\ldots \ldots \ldots, 122 \frac{1}{2} \mathrm{~mm}$. $\begin{array}{lll}\text { ditto } & \ldots \ldots & 122 \frac{1}{2} \\ \text { ditto } & \ldots \ldots & 126\end{array}$

Intermediate ....... $112 \mathrm{~mm}$.

ditto $\ldots \ldots \ldots, 120$,

ditto $\ldots \ldots \ldots 126$,

ditto $\quad \ldots \ldots \ldots, 139 \frac{1}{2}$,

ditto $\ldots \ldots .140$,

Intermediate ...... $137 \mathrm{~mm}$.

ditto $\quad . . \ldots . .134 \frac{1}{2}$,

ditto $\quad \ldots \ldots \ldots 140,140$

ditto $\ldots \ldots . .124$,

Intermediate $\ldots \ldots \ldots 114 \frac{1}{2} \mathrm{~mm}$.

ditto $\quad \ldots \ldots \ldots 117^{2}$,

ditto $\ldots \ldots \ldots, 122$,

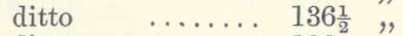

ditto ....... 126 ,

ditto $\ldots \ldots \ldots 126 \frac{1}{2}$,

ditto $\ldots \ldots \ldots, 120$,

Intermediate $\ldots \ldots \ldots \quad 116 \frac{1}{2} \mathrm{~mm}$.

$\begin{array}{llll}\text { ditto } & \ldots \ldots \ldots & 132 & \\ \text { ditto } & \ldots \ldots & 126\end{array}$

Mean length of intromittent organ, $126.92 \mathrm{~mm}$. 
TABLE 6. $-\mathrm{F}_{2}$ males from the fourth pair of $\mathrm{F}_{1}$ hybrids. Plate 45 . 27 specimens.

Photos. Genital spot.

$42 \ldots$ 1st (upper) bug intermediate. 2nd $"$ ditto. 3rd ... ditto. 4th " $\quad$ E. servus.

43 ... 1st (upper) bug intermediate. 2nd $"$ ditto. 3rd $"$ ditto. 4th $\quad " \quad$ E. servus. 5th $"$ ditto. 6th, ditto. 7th,$\quad$ ditto.

44 ... 1st (upper) bug intermediate. 2nd,$\quad$ ditto.

45 ... 1st (upper) bug intermediate. 2nd $"$ ditto. 3rd , ditto.

$46 \quad \ldots \quad$ 1st (upper) bug $E$. variolarius. 2nd " intermediate. 3rd $\quad$ E. variolarius. 4th , , ditto. 5th .., intermediate. 6th $"$ ditto.

47 ... 1st (upper) bug intermediate. 2nd $\quad$ ditto. 3rd " ditto. 4th,$\quad$ ditto.

$48 \quad \ldots$ E. variolarius.
Intromittent organ. $\times 20$ diams. Intermediate ...... $142 \mathrm{~mm}$. ditto $\ldots \ldots \ldots, 130$., ditto ...... $130 \frac{1}{2}$, ditto ....... 136 ,

Intermediate ...... $118 \frac{1}{2} \mathrm{~mm}$. ditto $\ldots \ldots \ldots .132$, ditto ...... 140 , ditto $\ldots \ldots .133$, ditto $\ldots \ldots \ldots, 127$, ditto $\ldots \ldots, 138$, ditto $\ldots \ldots .141 \frac{1}{2}$,

Intermediate ...... $115 \mathrm{~mm}$. ditto $\ldots \ldots .127$,

Intermediate ....... $128 \mathrm{~mm}$. ditto $\ldots \ldots .136$, ditto ...... 137 ,

Intermediate $\ldots \ldots \ldots 116 \frac{1}{2} \mathrm{~mm}$. ditto ....... 128 , ditto ...... 122 , ditto ....... 120 , ditto $\ldots \ldots \ldots, 136$, ditto $\ldots \ldots .6127$,

Intermediate ...... $119 \frac{1}{2} \mathrm{~mm}$. ditto $\ldots \ldots .110$, ditto $\ldots \ldots \ldots, 142$, ditto $\ldots \ldots, 121$,

Intermediate ....., $110 \mathrm{~mm}$.

Mean length of intromittent organ, $128.27 \mathrm{~mm}$.

TABLE 7.- $\mathrm{F}_{2}$ males from the fifth pair of $\mathrm{F}_{1}$ hybrids. (4 specimers.) Photos 15-16, Plate 41.

\section{Photos.}
15 .... 1st (upper) bug E. variolarius. 2nd, intermediate. 3rd $\quad$ ditto,

Intromittent organ. $\times 20$ diams. Intermediate ...... $108 \mathrm{~mm}$. ditto $\quad \ldots \ldots \ldots 107 \frac{1}{2}$, E. servus $\quad \ldots \ldots \ldots 147 \quad$, Intermediate ...... $135 \mathrm{~mm}$.

Mean length of intromittent organ, $124.37 \mathrm{~mm}$. 
TABLE 8. $-\mathrm{F}_{2}$ males from the sixth pair of $\mathrm{F}_{1}$ hybrids. (6 specimens.) Photos 49-50, Plate 45.

Photos.

49 .... 1st (upper) bug intermediate. 2nd $" E$ servus.

$50 \quad \ldots .1$ 1st (upper) bug intermediate. $\begin{array}{lll}\text { 2nd } & \text { ditto. } \\ \text { 3rd } & " & \text { ditto. } \\ \text { 4th } & " & \text { ditto. }\end{array}$
Intromittent organ. $\times 20$ diams.

Intermediate ....... $113 \frac{1}{2} \mathrm{~mm}$. ditto $\quad \ldots \ldots \ldots+129 \frac{1}{2}$,

Intermediate ....... $128 \mathrm{~mm}$

$\begin{array}{llll}\text { ditto } & \ldots \ldots \ldots & 128 & \\ \text { ditto } & \ldots \ldots & 125 & \\ \text { ditto } & \ldots \ldots & 134 & \end{array}$

Mean length of intromittent organ, $126 \cdot 33 \mathrm{~mm}$.

TABLE 9. $-\mathrm{F}_{2}$ males from the seventh pair of $\mathrm{F}_{1}$ hybrids. Plate 46. (32 specimens.)

Thotos.

51 .... 1st (upper) bug intermediate.

2nd $" \quad E$. servus.

3rd " ditto.

4th " " intermediate,

5th " " E. servus.

6th, ditto.

7th, ditto.

8th,$\quad$ ditto.

9th " $\quad$ intermediate.

$52 \quad \ldots \quad$ 1st (upper) bug E. servus.

2nd

3rd ," ditto.

4th " $\quad$ E. servus.

5th " $"$ ditto.

6th " ditto.

$53 \ldots$ 1st (upper) bug intermediate.

2nd $"$ ditto.

3rd ..." ditto.

4th " E. servus.

54 ... 1st (upper) bug intermediate.

2nd " ditto.

3rd " E. servus.

4 th " intermediate.

$55 \quad \ldots \quad$ 1st (upper) bug $E$. variolarius. 2nd ," intermediate.

3rd " ditto.

4th $\quad$, E. servus.

56 ... 1st (upper) bug E. variolarius. 2nd " intermediate. 3rd ...." E. servus.

$57 \ldots . \quad 1$ st (upper) bug intermediate. und " ditto.
Intromittent organ. $\times 20$ diams.

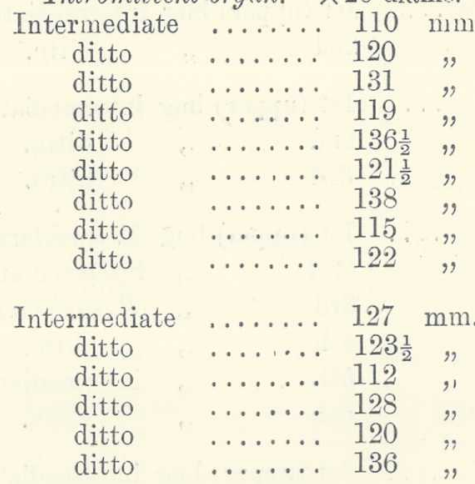

Intermediate ....... $115 \frac{1}{2} \mathrm{~mm}$.

ditto ....... 112 ,

ditto ....... 115 "

ditto $\quad \ldots \ldots \ldots \quad 143 \frac{1}{2}$,

Intermediate $\ldots \ldots \ldots, 130 \mathrm{~mm}$.

ditto $\quad \ldots \ldots .6120$,

ditto $\ldots \ldots \ldots 135$,

ditto $\ldots \ldots \ldots, 112$,

Intermediate $\ldots \ldots \ldots, 116 \frac{1}{2} \mathrm{~mm}$.

ditto $\ldots \ldots \ldots 118$

ditto $\ldots \ldots \ldots 118$,

ditto ....... 131 ",

Intermediate ...... $112 \frac{1}{2} \mathrm{~mm}$.

ditto $\quad$....... 119 ,

ditto ...... 129 $\frac{1}{2}$,

Intermediate $\ldots \ldots \ldots, 106 \frac{1}{2} \mathrm{~mm}$. ditto $\ldots \ldots \ldots, 120^{2}$,

Mean length of intromitient organ, $122 \cdot 29 \mathrm{~mm}$. 
TABLE 10.-Summary of the above detailed results.

\begin{tabular}{|c|c|c|c|c|c|c|}
\hline . & 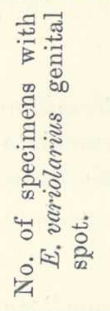 & 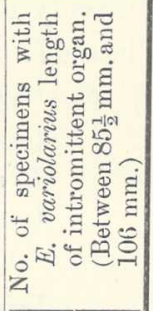 & 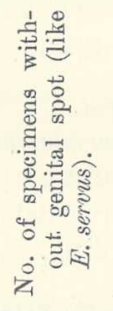 & 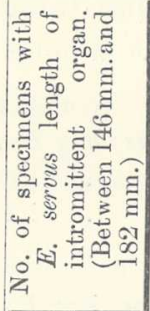 & 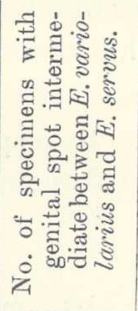 & 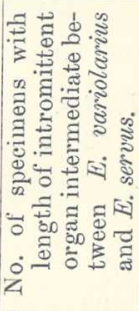 \\
\hline $\begin{array}{l}\mathrm{F}_{2} \text { males trom 1st } \\
\text { pair of } \mathrm{F}_{1} \text { hybrids } \\
\text { (43 specimens). } \\
\text { Photos } 17-25 .\end{array}$ & 1 & 9 & 25 & 5 & 17 & 29 \\
\hline $\begin{array}{l}\mathrm{F}_{2} \text { males from 2nd } \\
\text { pair of } \mathrm{F}_{1} \text { hybrids } \\
\text { ( } 30 \text { specimens). } \\
\text { Photos } 26-32 .\end{array}$ & 3 & 4 & 15 & 0 & 12 & 26 \\
\hline $\begin{array}{l}\mathrm{F}_{2} \text { males from 3rd } \\
\text { pair of } \mathrm{F}_{1} \text { hybrids } \\
\text { (48 specimens). } \\
\text { Photos } 33-41 .\end{array}$ & 8 & 1 & 13 & 1 & 27 & 46 \\
\hline $\begin{array}{l}\mathrm{F}_{2} \text { males from } 4 \text { th } \\
\text { pair of } \mathrm{F}_{1} \text { hybrids } \\
\text { ( } 27 \text { specimens). } \\
\text { Photos } 42-48 .\end{array}$ & 4 & 0 & 5 & 0 & 18 & 27 \\
\hline $\begin{array}{l}\mathrm{F}_{2} \text { males from } 5 \text { th } \\
\text { pair of } F_{1} \text { hybrids } \\
\text { ( } 4 \text { specimens). } \\
\text { Photos } 15-16 .\end{array}$ & 1 & 0 & 1 & 1 & 2 & 3 \\
\hline $\begin{array}{l}\mathrm{F}_{2} \text { males from } 6 \text { th } \\
\text { pair of } \mathrm{F}_{1} \text { hybrids } \\
\quad(6 \text { specimens }) . \\
\text { Photos } 49-50 .\end{array}$ & 0 & 0 & 1 & 0 & 5 & 6 \\
\hline $\begin{array}{l}\mathrm{F}_{2} \text { males from } 7 \mathrm{th} \\
\text { pair of } \mathrm{F}_{1} \text { hybrids } \\
\text { (32 specimens). } \\
\text { Photos } 51-57 .\end{array}$ & 2 & 0 & 14 & 0 & 16 & 32 \\
\hline Totals ...... & 19 & 14 & 74 & 7 & 97 & 169 \\
\hline
\end{tabular}

Mean length of intromittent organ of the $190 \mathrm{~F}_{2}$ hybrids, $124 \cdot 42 \mathrm{~mm}$. 
TABLe 11.-Lengths of the intromittent organs in the 18 males from the Backcross (i.e. $\mathrm{F}_{1}$ i $\times$ pure variolarius $\delta$ ), side by side with the inheritance of the E. variolarius genital spot. A comparison demonstrates again that these two exclusively male characters are not linked. in inheritance. Photos 62-66, Plate 4\%.

Photos. Genital spot.

62 ... 1st (upper) bug $E$. variolarius. 2nd

3rd

4 th

$\begin{array}{lc}" & \text { ditto. } \\ " & \text { intermediate. } \\ & \text { ditto. }\end{array}$

63

... 1st (upper) bug $E$. variolarius. 2nd

3rd

4 th

"

ditto.

ditto.

ditto.

$64 \quad \ldots$ 1st (upper) bug $E$. variolarius.

65

$\ldots$

66 2nd

3rd

4 th

5 th

6 th

ditto.

intermediate.

" E. variolarius.

intermediate.

E. variolarius.

E. variolarius.

$\begin{array}{llc}\text { 1st (upper) bug } E \text {. variolarnus. } \\ \text { 2nd } & \text { intermediate. } \\ \text { 3rd } & ", & \text { ditto. }\end{array}$

Intromittent organ. $\times 20$ diams.

Intermediate ....... $112 \frac{1}{2} \mathrm{~mm}$.

E. variolarius ........ 105,

Intermediate $\ldots \ldots \ldots$ 128 $\frac{1}{2}$,

ditto $\quad \ldots \ldots, 117$,

Intermediate $\ldots \ldots \ldots, 110 \frac{1}{2} \mathrm{~mm}$.

ditto $\ldots \ldots \ldots .116$,

E. variolarius $\ldots \ldots \ldots . .106$,

Intermediate ...... 107 ,

Intermediate ...... $115 \mathrm{~mm}$.

ditto $\ldots \ldots \ldots$. $112 \frac{1}{2}$,

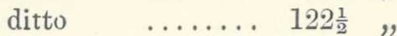

E. variolarius $\quad \ldots \ldots \ldots, 102$,

Intermediate $\ldots \ldots \ldots, 119$,

ditto $\ldots \ldots . .118$,

Intermediate $\ldots \ldots \ldots \quad 113 \frac{1}{2} \mathrm{~mm}$.

Intermediate ....... $114 \frac{1}{2} \mathrm{~mm}$.

ditto $\quad \cdots \cdots \cdots \cdot 116 \frac{1}{2}$,

ditto $\quad \ldots \ldots .106 \frac{1}{2}$,

Mean length of intromittent organ, $113.47 \mathrm{~mm}$.

It is an interesting fact that Mendel's Law of Heredity owed its inception in part to an analytical study of a size-character-the character which has. proved on further investigation to be the greatest stumbling-block to an unqualified acceptance of the law as a wholly satisfactory explanation of the problems of heredity. In his original work on tall and dwarf peas, Mendel found that two lengths so far apart as $6 \mathrm{ft}$. and $1 \frac{1}{2} \mathrm{ft}$. acted as unit characters, and these characters showed dominance and segregation.

More recent work on size-relations has led to an accumulation of facts showing that in the majority of cases dominance and segregation in the Mendelian ratios of $1-2-1$ are not present; and many Mendelians have made ingenious efforts to reconcile these facts with their conception of Mendelism by adding a superstructure to Mendel's original law, which has called forth an earnest protest from certain investigators.

Castle was the first Mendelian to demonstrate a case in which dominance. and segregation were found to be absent where a length-character was. carefully studied. He crossed the long-eared lop rabbit with the ordinary short-eared type, and found the $\mathrm{F}_{1}$ generation with ears intermediate in 
length, and no Mendelian segregation in the $\mathrm{F}_{2}$ generation. These facts, together with further studies on size-relations, followed by his striking results in selection (Castle, '12 \& '14), have led him to question certain hypotheses which he believes are quite unnecessary adjuncts to Mendelism.

As Castle believes that both small and large variations are inherited, he questions the mutation theory which claims "that only variations of some size are inherited".

As he believes in quantitative variations of unit characters, he questions the multiple factor hypothesis.

As he has demonstrated that quantitative variations can be increased by selection, he questions the hypothesis which denies this possibility (genotype theory).

Of unit characters he says: "In my experience every unit eharacter is subject to quantitative variation, that is, its expression in the body varies, and it is clear that these variations have a germinal basis because they are inherited."

"It is the substantial integrity of a quantitative variation from cellgeneration to cell-generation that constitutes the basis of Mendelism. All else is imaginary." (Castle, '12a.)

Castle has arrived at his present conception of Mendelism through his extended and thoroughly scientific experiments on quantitative variations; and the results of his experimental studies of size-differences appear to be so completely in harmony with the results of our cross-breeding experiments with Euschistus, that we shall give a brief summary of his observations before we present the facts which seem to us to support them.

His wide experience in experimental breeding in relation to size-characters entitles him to speak with authority on this subject.

His observations may be briefly stated as follows :-

First. Dominance is absent in the $\mathrm{F}_{1}$ hybrid generation.

Second. The $\mathrm{F}_{1}$ hybrids are intermediate in size.

Third. Mendelian segregation is absent in the $\mathrm{F}_{2}$ hybrid generation.

Fourth. There is increased variability in the $\mathrm{F}_{2}$ generation as compared with the $\mathrm{F}_{1}$ generation.

Fifth. The $\mathrm{F}_{2}$ generation, like the $\mathrm{F}_{1}$, is intermediate in size.

Sixth. Both extremes in size of the original parents may be found in the $\mathrm{F}_{2}$ generation, but not in the $\mathrm{F}_{1}$ generation.

Seventh. Size-characters, in common with all characters (even those that Mendelize), show quantitative variation.

We shall compare these observations with our own results, and when making this comparison we shall consider first the intromittent organ, and then the genital spot, in order to point out that the results from these two exclusively male characters are identical. 
"First. Dominance is absent in the $F_{1}$ hybrid generation."-This is supported by our measurements of the intromittent organ; for not one of the ten ${ }^{*} \mathrm{~F}_{1}$ hybrids has a length of intromittent organ that comes within the range characteristic of either variolarius or of servus. They are all intermediate: one measures $109 \mathrm{~mm}$., one $122 \mathrm{~mm}$., two $124 \mathrm{~mm}$., four $126 \mathrm{~mm}$., one $132 \mathrm{~mm}$., and one $134 \mathrm{~mm}$. $†$

Absence of dominance is equally evident in the case of the genital spot; for nine of the eleven $\mathrm{F}_{1}$ hybrids are variable intermediates, while only two are like one of the parent species-i. e., like servus in having no spot.

"Second. The $F_{1}$ hybrids are intermediate ir size."-This is quite true for both the intromittent organ and the genital spot, though it can be more clearly demonstrated in the former.

The mean length of the intromittent organ of Euschistus variolarius is $96.70 \mathrm{~mm}$. (Table 1), and that of E. servus is $166.41 \mathrm{~mm}$. (Table 2). A precise intermediate between these two means would be $131.55 \mathrm{~mm}$. (i. e., $34.85 \mathrm{~mm}$. above the mean of $E$. variolarius or below the mean of $E$. servus).

The mean length of the organ in the $\mathrm{F}_{1}$ hybrids computed from the ten specimens is $124.9 \mathrm{~mm}$, which is slightly below the precise intermediate (131.55 mm.), and shows therefore a stronger inheritance from $E$. variolarius than from $E$. servus. The exact length of each specimen, as stated above, shows the $\mathrm{F}_{1}$ intromittent organs to be very variable intermediates, ranging: between $109 \mathrm{~mm}$. and $134 \mathrm{~mm}$. in length.

In the case of the genital spot the slightly stronger inheritance is from $E$. servus instead of from $E$. variolarius, for two of the eleven hybrids are like servus in having no spot. The remaining nine specimens are variable intermediates (photos 8 to 14, Plate 28 of this volume), and therefore the genital spot as well as the intromittent organ may be said to be approximately intermediate in size between the two parent species.

"Third. Mendelian segregation is absent in the $F_{2}$ hybrid generation."In our study of the transmission of the genital spot of variolarius (Foot and Strobell, '14 a) we divided the hybrids into three groups-those having a genital spot like those of pure variolarius, those without a spot like servus, and those with a spot intermediate between these two extremes. In the case of the intromittent organ we have grouped the hybrids into three similar classes--those having a length of intromittent organ within the range of that of variolarius, those with a length of organ within the range of that of servus, and those with a length intermediate between the longest found in variolarius and the shortest found in servus.

If we are looking for a simple Mendelian segregation of 1-2-1 and assume that the heterozygotes are represented by the intermediates, we should

* The intromittent organ of the eleventh $\mathrm{F}_{1}$ hybrid was destroyed in dissection.

$\dagger$ These lengths are given in connection with each photograph ( 7 to 14), and can therefore be compared with the inheritance of the genital spot. 
expect to find these two exclusively male characters in the $\mathrm{F}_{2}$ hybrids in the following ratio:-25\% like variolarius, $25 \%$ like servus, and $50 \%$. intermediates. We ought to find 47 of the $190 \mathrm{~F}_{2}$ hybrids like variolarius, 47 like servus, and 94 intermediates; whereas we find in the case of the intromittent organ 14 like variolarius, 7 like servus, and 169 intermediates (see Table 10), and in the case of the genital spot 19 like variolarius, 74 like servus, and 97 intermediates (Table 10). Both characters-the intromittent organ and the genital spot-are therefore like other size-characters in their failure to show Mendelian segregation in the $\mathrm{F}_{2}$ generation.

"Fourth.-There is increased variability in the $F_{2}$ generation as compared with the $F_{1}$ generation." - This appears at first sight to be true both for the intromittent organ and for the genital spot, but the evidence is unsatisfactory in that the number of individuals is so very different for the two generations, and, as variation is present in both generations, we must expect the larger number to give the larger number of variations. We have the exact length of the intromittent organ for 190 specimens of the $\mathrm{F}_{2}$ generation, but have it for only 10 of the $F_{1}$ generation. There are 69 variations of length in the $190 \mathrm{~F}_{2}$ hybrids (Tables 3 to 9 ), and only six variations in the ten $\mathrm{F}_{1}$ hybrids. The latter, however, represents more variations in relation to the number of specimens than the 69 variations in the $190 \mathrm{~F}_{2}$ hybrids.

These relations hold true also in the case of the genital spot, though the evidence here is not so exact, as the differences cannot be accurately measured as in the case of the intromittent organ.

On the whole we are not justified in claiming that the evidence is in accord with the observations on those size-characters which show that "there is increased variability in the $F_{2}$ generation as compared to the $\mathrm{F}_{1}$ generation".

"Fifth. The $F_{2}$ generation, like the $F_{1}$, is intermediate in size."-This point can again be most satisfactorily demonstrated in the case of the intromittent organ, for we know the mean length of the organ for both parent species, for the $\mathrm{F}_{1}$ generation, the $\mathrm{F}_{2}$ generation, and for the seven separate families of these $\mathrm{F}_{2}$ hybrids.

As stated above, the theoretically precise intermediate between theimean lengths of the two parent species would be $131.55 \mathrm{~mm}$.

The following are the mean lengths of intromittent organ of the $\mathrm{F}_{2}$ males. from the seven pairs of $\mathrm{F}_{1}$ hybrids :-

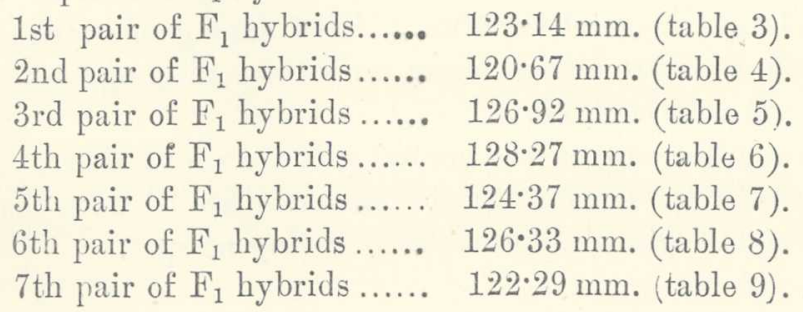


The mean length of the intromittent organ computed from the total number of $\mathrm{F}_{2}$ males (190 specimens) is $124.42 \mathrm{~mm}$. A comparison of this with the mean length of the organ of the $F_{1}$ hybrids $(124.9 \mathrm{~mm}$.) shows that the mean length is almost the same for both the first and second generations, differing only by a few hundredths of a millimetre. It is clear therefore that the $\mathrm{F}_{2}$ generation, like the $\mathrm{F}_{1}$, is intermediate in size, and both agree further in showing a stronger inheritance from variolarius than from servus. This is true not only when the total number of $\mathrm{F}_{2}$ hybrids is considered, but holds for each individual family of the $\mathrm{F}_{2}$ generation-each of the seven families has a mean length of intromittent organ which is below the theoretical intermediate between the parent species $(131.55 \mathrm{~mm}$.).

"Sixth. Both extremes in size of the original parents may be found in the $F_{2}$ generation, but not in the $F_{1}$ generation."-As the two characters we are testing are exclusively male, we can compare our results with the above observation only in the case of the original male parent. The length of the intromittent organ of the original E. servus male parent of the first cross is $166 \mathrm{~mm}$., a length which has not been reached in any of the 190 specimens of the $\mathrm{F}_{2}$ generation, the longest intromittent organ of all these $\mathrm{F}_{2}$ hybrids measuring only $152 \mathrm{~mm}$. (Table 3), and in only one specimen of the 190 was this length attained. We therefore cannot say that the length of the intromittent organ of this grandparent is found in our $\mathrm{F}_{2}$ generation. If we disregard this length and take into consideration the mean length of the organ both in servus and in variolarius, we then find that a length of intromittent organ characteristic of both species is represented in the $\mathrm{F}_{2}$ generation, and we find a still larger number like the two species, if we consider all the $\mathrm{F}_{2}$ hybrids which have a length of organ within the limits of length characteristic of variolarius and servus. For example, $14 \mathrm{~F}_{2}$ hybrids are like variolarius in having the length of intromittent organ $106 \mathrm{~mm}$. or less, and 7 are like servus in having the length of intromittent organ $146 \mathrm{~mm}$. or more (Tables 3 to 10 ).

Among the ten $\mathrm{F}_{1}$ hybrids we find none with a length of organ like E. variolarius (106 mm. or less) nor any like E. servus (146 mm. or more), but we are inclined to believe that this is due to the relatively small number of specimens. As stated above, the relative number of variations in length of the intromittent organ of the ten $F_{1}$ hybrids is greater than that of the $F_{2}$ generation, and therefore we should expect a larger number of specimens to give us a larger range of variation. Even among these ten specimens we have one with the intromittent organ only $109 \mathrm{~mm}$. long, and this is within $3 \mathrm{~mm}$. of the variolarius type.

The results in the case of the genital spot are very similar. Nine of the eleven $\mathrm{F}_{1}$ hybrids have a spot variably intermediate between that of the two parent species, but two are like servus in having no spot. 
In the $\mathrm{F}_{2}$ generation the extremes of the genital spot $(i . e$. , its full size and its complete absence) are represented, 19 of the $\mathrm{F}_{2}$ hybrids having a genital spot almost if not quite as pronounced as the pure variolarius species, and 74 having no spot like E. servus.

"Seventh. Size-characters, in common with all characters (even those that Mendelize), show quantitative variation." -Quantitative variation is of course more accurately demonstrated in the case of the intromittent organ than in the genital spot, though it is present in both these characters. Table 1 shows that in 62 specimens of $E$. variolarius the length of the organ varied between $85 \frac{1}{2} \mathrm{~mm}$. and $106 \mathrm{~mm}$, the range of the variation between the shortest and the longest being $20.5 \mathrm{~mm}$. The table gives the number of specimens having the various lengths, and it demonstrates that there is no definite ascending or descending scale of variation in relation to the number of specimens having a given length of the organ, though the extremes are represented by only one specimen, and lengths near the mean are more frequently represented.

This is true also for E. servus as demonstrated in Table 2. This table gives the lengths of the intromittent organs for 62 specimens, and shows that this length varies between $146 \mathrm{~mm}$. and $182 \mathrm{~mm}$., the range of the variation between the shortest and the longest being therefore $36 \mathrm{~mm}$.

Variations in the length of the intromittent organ may be quite independent of the relative size of the insects, not only in the hybrid generations, but also in the pure species: for example, the photographs of the two intromittent organs shown in photo 6 measure $104 \mathrm{~mm}$. and $94 \mathrm{~mm}$. The two insects from which these organs were taken are brothers of the $E$. variolarius female of the original cross. The one having the longer intromittent organ (104 mm.) is decidedly the smaller insect, the actual width of the pronotum (between the humeri) being $8 \frac{1}{2} \mathrm{~mm}$., while the pronotum of the insect with the shorter organ measured $9 \frac{1}{2} \mathrm{~mm}$.

Quantitative variation in the genital spot, though more difficult to demonstrate than in the intromittent organ, can be appreciated by comparing. the male offspring from the same parents.

It is clear that all the points taken up under the above seven headings apply to the genital spot with quite as much force as to the intromittent organ-the size of the genital spot, like the length of intromittent organ, showing a type of inheritance that is nearly in full accord with Castle's observations on size-characters. In earlier papers these facts were clearly stated in the case of the genital spot (Foot and Strobell, '13 \& '14a), but it is interesting to note that Morgan ('14) interprets such evidence quite differently from Castle, for he says, "the authors' evidence shows that it (the genital spot) is inherited as are Mendelian characters" (page 481).

We do not feel justified, in view of the narrow limits of our experiments in genetics, in attempting to draw conclusions as to the possible bearing of 
our results on Mendelism, or on the many ingenious hypotheses designed to. adapt Mendel's law to some later experimental results. As, however, we arein entire sympathy with Castle's interpretation of size-characters, and beliere. his thorough knowledge of the subject entitles him to speak with authority, we would quote some of his recent conclusions that appear to us as sustained by the facts of our experimental work on both the intromittent organ and the genital spot of Euschistus.

Castle says:- "It is evident that size is not a simple unit character, for there is no dominance and no evidence of segregation other than the. increased variability of the second hybrid generation. ....

"Dominance is clearly absent and the only fact suggesting segregationis the increased variability of the second as compared with the first hybrid generation. This fact, however, may be accounted for on other grounds than the existence of multiple units of varying power.

"If size-differences are due to quantitative variations in special materials. within the cell, it is not necessary to suppose that these materials are localized in chunks of uniform and unvarying size, or that they occur in any particular number of chunks, yet the genotype hypothesis involves one or both of these. assumptions. Both are unnecessary." (Castle, '12 a.)

"The results of all observers, as regards the inheritance of ordinary differences in size, are closely in accord. When two races differing in size are crossed the immediate offspring are intermediate in size. The next generation of offspring is likewise intermediate, but more variable as a rule, and it has been found possible in some cases to select from them forms as extreme in size as the original parents. To interpret such cases as Mendelian, requires the assumption that no single unit or factor is concerned in the sizedifference, but many wholly independent units. For a single Mendelizing unit would produce a wholly different result. But suppose we allow the assumption that many independent Mendelizing units or factors are concerned. in the inheritance of size. The pure line hypothesis is not benefited by this assumption unless we suppose further that these hypothetical factors do not vary. But this is an assumption wholly without warrant." (Castle, '14 b.)

"The increased variabitity of the $\mathrm{F}_{2}$ generation is the only evidence of Mendelism in size crosses." ....

"On any bypothesis size-differences must depend on many mutrally independent factors or causes... It would be rash to assume that all the factors concerned are Mendelizing factors, in the total absence of the two usual accompaniments and criteria of Mendelism, dominance and segregation in recognisable Mendelian ratios." (Page 2.)

He says the facts observed for body-size in rabbits and other quantitatire characters in animals and plants are, $\mathrm{F}_{1}$ intermediate and $\mathrm{F}_{2}$ also intermediate, but more variable than $\mathrm{F}_{1}$, and he adds, "If we call this Mendelism, we shall need to explain that it is not the Mendelism of Mendel himself, but original. 
Mendelism, plus (1) the assumption of gametic purity, plus (2) the assumption of factorial constancy, plus (3) the assumption of factorial multiplicity" (Castle, '14 $a$ ).

Results from backcross. $\quad \mathrm{F}_{1}$ hybrid female (from E. variolarius 우 $\times$ E. servus $\mathrm{o}$ ) by pure E. variolarius male. 18 males, photos 62-66.

This backeross was undertaken to obtain evidence as to whether the socalled male- and female-producing spermatozoa differ in their function in the transmission of the exclusively male character-the genital spot (Foot and Strobell, '13 \& '14). We shall briefly re-state this evidence here in order to show that the original results are duplicated by the facts demonstrated in this paper as to the method of transmission of a second exclusively male character-the intromittent organ.

First, the so-called male-producing spermatozoon can transmit the genital spot. This was proved by the fact that the genital spot in the 18 males from this backcross is inherited much more strongly from the pure variolarius male than from the $\mathrm{F}_{1}$ hybrid males, and therefore this variolarius character was transmitted directly from the male to its male offspring, and must, according to the hypothesis, have been transmitted by the male-producing spermatozoa * This evidence is repeated in the case of the intromittent organ, for the mean length of the intromittent organ of these 18 males is $113.47 \mathrm{~mm}$., while the mean length of the organ of the $\mathrm{F}_{2}$ generation is $124.42 \mathrm{~mm}$.- the measure therefore of the influence of the pure variolarius male in reducing the length of the intromittent organ may be expressed as $10.95 \mathrm{~mm}$.

Second, this backcross demonstrated in the case of the genital spot that the servus character-the absence of spot-was transmitted by the so-talled female-producing spermatozoon ; and this evidence of the transmission of an exclusively male character by the female-producing spermatozoon is repeated in the case of the intromittent organ, for the length of the intromittent organ in these 18 males has been increased by the inheritance from servus. This is demonstrated by the fact that the mean length of the intromittent organ of the 18 males from this backcross is $113.47 \mathrm{~mm}$., while that of the organ of the 62 pure variolarius males is $96.70 \mathrm{~mm}$. The two servus charactersabsence of spot, and increased length of intromittent organ - must have been transmitted (according to the hypothesis) by the so-called female-producing spermatozoon of servus to the pure variolarius of of the first eross, through which it was transmitted to her daughter, the $\mathrm{F}_{1}$ o of this backeross.

The demonstration that the so-called sex-determining spermatozoa do not differ functionally in the transmission of such an exclusively male character

* In making these deductions it is of course necessary to accept, for the sake of the argument, the assumption of male- and female-producing spermatozon, an assumption which we believe is still far from proved.

LINN. JOURN.-ZOOLOGY, VOL. XXXII. 
as the genital spot would seem to justify a good deal of scepticism of the sex-determination theory which is based on the assumption of male- and female-producing spermatozoa. This scepticism is greatly strengthened by the further evidence that these so-called male- and female-producing spermatozoa do not differ functionally in the transmission of such an exclusively male sexual character as the intromittent organ itself. Further, it seems only logical to believe, if exclusively male sexual characters are transmitted by both inale- and female-producing spermatozoa, the same must be true also for the exclusively female sexual characters, for it is difficult to believe that the two sexes can have such fundamentally different modes of transmission.

If we measure the amount of the variolarius inheritance in this backcross, we find an astonishing agreement between the theoretical expectation and the actual result. The relative amount of variolarius to servus in the offspring of this backeross is 3 to 1 , and we should expect, therefore, the mean length of the intromittent organ of servus to be reduced by 75 per cent. of the difference between the mean lengths in variolarius and servus. This difference is $69.71 \mathrm{~mm}$., 75 per cent. of this being $52.28 \mathrm{~mm}$. Deducting this from the mean length of the organ of servus $(166.41 \mathrm{~mm}$.) would leave $114 \cdot 13 \mathrm{~mm}$. as the mean length of the organ of the offspring from this backcross. The mean length is in fact $113.47 \mathrm{~mm}$., this being only $0.66 \mathrm{~mm}$. less than the calculated expectation.

These results lose much of their significance in view of the fact that only eighteen males were secured from this backcross, but the results are almost exactly repeated by a backcross with $E$. ictericus, in which 70 instead of 18 males were raised *.

The above method of computing the mean length of organ to be expected in the offspring from the two species, by a simple measure of the relative part each species has contributed in the crossings, is of interest only because the calculated results seem to fit the facts, but it certainly can have no bearing on cases that show the Mendelian type of inheritance, nor where simple unit characters are involved. Neither does it apply to the $\mathrm{F}_{2}$ generation, for in each of the seven families the mean length is below an exact intermediate.

Table 11 demonstrates that the intromittent organs from the offspring of this backeross fail to show a typicai Mendelian ratio, and as this is true also in the case of the genital spot, it is a further proof of the complete agreement. in the results obtained from these two exclusively male characters.

* The mean length of the intromittent organ of the offspring from the variolarius-ictericus cross is also only a fraction of a millimetre less than the theoretical expectation, but in this cross the slightly stronger inheritance is from the original male parent, while in the variolarius-servus cross it is from the original female parent. In both crosses, however, the stronger inheritance is slightly on the side of the shorter type of intromittent organ. Our results from the variolarius-ictericus cross will be published shortly, 


\section{Linkage.}

To the cytologist, linkage of characters in inheritance is of special interest because it is claimed that it affords the most trustworthy evidence that the factors determining linked characters are located in the same chromosome, and further it is claimed that this chromosome can be identified. Wilson has recently expressed this view clearly in his Croonian Lecture ('14). After giving a brief summary of the work of Morgan and his pupils on linked characters in Drosophila, he adds :-

"This at once suggests that the units of each group (or corresponding things on which they depend) are borne by a particular chromosome which constitutes their common vehicle of transmission, and that to this fact is due their cohesion or linkage in heredity. Jonversely, the several groups are independent of one another, because of the independence of the chromosomes which bear them." (Page 344.)

If, as Wilson says, independence in the transmission of characters is due to independence of the chromosomes which bear them, the evidence obtained from our cross-breeding experiments would indicate that the factors determining the transmission of the intromittent organ are not only not carried by a single pair of chromosomes; but on the above hypothesis it would seem difficult to confine them to the 14 chromosomes, for among the $190 \mathrm{~F}_{2}$ hybrids there are 69 different lengths of the intromittent organ, and if size-variations are due to multiple unit factors which are transmitted as independent units, these 69 variations would seem to demand an explanation from those who believe that " unit factors" are located in the chromosomes. Further, none of these 69 variations in the $\mathrm{F}_{2}$ hybrids is consistently linked with any of the variations of the genital spot. We might reduce the number of independent variations of the intromittent organ and the genital spot by consigning most of them to the convenient class called "non-inheritable fluctuations", but this rather arbitrary process must be carried far, if the remaining "unit factors" are to be consigned to a single pair of chromosomes.

The "cross-over hypothesis", which was offered to explain unexpected results in the transmission of characters assumed to be carried by special chromosomes, might be used to excuse non-linkage in these extreme cases; but we cannot believe that it wonld be adequate to convince the unprejudiced investigator that the factors determining quantitative variations in the intromittent organ and genital spot are carried and distributed by the chromosomes. Even if we arbitrarily consign the determining factors to special positions in the chromosomes and dictate their subsequent method of division, it does not seem possible to adjust the facts with the view that linkage and non-linkage may have their explanation in chromosomedistribution of the factors. 
In our preliminary report of this work (Foot and Strobell, '14 c) we discussed the non-linkage of the genital spot and intromittent organ as follows :-

"If factors which stand for a given character are carried by a definite chromosome or pair of chromosomes, and the inheritance of the character is due to a special distribution of the factors at mitosis, it would seem logical to expect that the factors of two characters showing a very special mode of distribution (i.e., exclusively male characters) would be contained in the same chromosome, and that this would be indicated by their being linked in the hybrids. We would expect the absence or presence of the genital spot, distinctive of one species, to be associated in inheritance with the type of intromittent organ characteristic of the same species. Even if the extent to which a character appears is dependent upon hypothetical factors outside the chromosomes, we would expect these hypothetical factors to act equaliy on two characters which are so closely associated as to be contained in the same chromosome. We should expect the two characters never to be so entirely dissociated that we find, in the same individual, the absence of spot characteristic of one species, associated with the type of intromittent organ distinctive of the other speries. Instances of such complete dissociation do, however, occur.... There are instances of association in the inheritance of the two characters, the intromittent organ and genital spot, typical of one of the species occurring in the same $\mathrm{F}_{2}$ individual; but exact classification of the full results shows that the two characters are transmitted quite independently of each other. The intermediates, having a large range of variation, make it possible for many of them to appear to show the two characters in the association that would be in harmony with the chromosome-hypothesis, but an exact comparison shows two plus and two minus intermediates are quite as frequently associated as are a plus and a minus intermediate."

These facts are demonstrated in the foregoing tables (3-9), in which the type of inheritance of the genital spot and the length of intromittent organ in each particular insect of the $\mathrm{F}_{2}$ generation are placed side by side. If we examine this evidence in detail, we find that 19 of these $190 \mathrm{~F}_{2}$ males have a genital spot quite as strong as that of the pure E. variolarius male, while only 3 of these 19 males have the $E$. variolarius length of intromittent organ (i.e., between $85 \frac{1}{2} \mathrm{~mm}$. and $106 \mathrm{~mm}$.).

This evidence of non-linkage is even more clearly shown in those insects which have inherited the servus character (absence of the genital spot). There are 74 of these insects, and only 3 have a length of intromittent organ which can be classed with servus, while on the other hand 4 have a length of intromittent organ characteristic of variolarius. The remaining 67 , which have the absence of genital spot characteristic of servus, have a mean length of intromittent organ which shows a stronger influence from variolarius.

Tables 3 to 10 further demonstrate that while the influence of variolarius 
is stronger than servus as regards the length of the intromittent organ, these relations are reversed in the case of the genital spot, and this is further demonstrated by those that are classed as intermediates, for of these more are minus than plus intermediates. It is therefore clear beyond question that these two exclusively male characters, the genital spot and the intromittent organ, are not linked in inheritance. These results are certainly out of harmony not only with the chromosome-hypothesis of sex-determination, but with the recent hypotheses of chromosome-distribution of unit factors.

The evidence from the $F_{1}$ generation is of less value, as we have only 11 specimens showing the inheritance of the genital spot, and we were not able to measure the length of intromittent organ of all the eleven, as one was destroyed in dissection.

The results from the $F_{1}$ generation are as follows:-2 of the eleven $\mathrm{F}_{1}$ hybrids are like servus in having no genital spot, and the remaining 9 are variable intermediates. The two that have the servus inheritance (without a genital spot) have the following lengths of intromittent organ-126 mm. and $124 \mathrm{~mm}$.; these lengths showing a stronger inheritance from variolarius as to the intromittent organ, while both insects show an exclusively servus inheritance in the absence of the genital spot.

The $\mathrm{F}_{1}$ hybrid that has the longest intromittent organ-134 mm. (photo 11) - has the strongest genital spot of all the eleven $\mathrm{F}_{1}$ hybrids, this again demonstrating a significant absence of linkage in these two exclusively male characters.

The mean length of the intromittent organs of the $10 \mathrm{~F}_{1}$ hybrids is $124.9 \mathrm{~mm}$., this demonstrating a stronger inheritance from variolarius than from servus. The difference between the mean length of variolarius $(96.70 \mathrm{~mm}$.) and of servus $(166.41 \mathrm{~mm}$.) is $69.71 \mathrm{~mm}$., and therefore an exact intermediate between these two means would be $131.55 \mathrm{~mm}$. 一the measure therefore of the stronger variolarius inheritance in these $\mathrm{F}_{1}$ hybrids may be expressed by $7 \cdot 46 \mathrm{~mm}$.

It is an interesting fact that the intromittent organ not only of this $\mathrm{F}_{1}$ generation, but also of the $\mathrm{F}_{2}$ generation, shows a stronger inheritance from variolarius than from servus, the measure of the greater variolarius influence being almost the same for the two generations, $i . e ., 7 \cdot 46 \mathrm{~mm}$. in the case of the $\mathrm{F}_{1}$ hybrids, and $7.13 \mathrm{~mm}$. in the case of the $\mathrm{F}_{2}$ hybrids.

While the intromittent organ of these 190 males shows a stronger inheritance from the female original parent (variolarius), the reverse is true of the genital spot, for only 19 of these 190 males have a spot as strong as variolarius, while 74 are like the male original part (sernus) in having no spot.

It is not possible to make an accurate estimate of the influence of the two species on the type of genital spot classed as intermediate, but there are certainly more minus than plus intermediates, this further demonstrating. that the genital spot shows a stronger inheritance from servus than from variolarius. 
The results from the backcross demonstrate again that the genital spot and the intromittent organ are not linked in inheritance (Table 11). Twelve of these eighteen specimens have the E. variolarius spot on the genital segment, while only three have a length of intromittent organ characteristic of variolarius. Six have a spot on the genital segment which is more or less reduced by the inheritance from $E$. servus, which has no genital spot. These six are therefore intermediate as to the genital spot, while there are fifteen intermediate in the length of the intromittent organ.

\section{Chromosomes.}

Our experiments with these hemiptera were undertaken with the aim of testing some recent chromosome-theories of sex-determination by the trustworthy method of experimental cross-breeding. For this purpose we selected an exclusively male character-the distinct dark spot which is present on the genital segment of Euschistus variolarius and absent in Euchistus servus, for this character appeared to us well adapted to test the function of the so-called sex-chromosomes in the transmission of an exclusively male character.

The results of these cross-breeding experiments and their bearing on the chromosome-theories of sex-determination have been discussed in earlier papers, Foot and Strobell, ' 13 and ' $14 a \& b$. In the present paper we will summarize the evidence in order to demonstrate that the results gained by the study of the transmission of the genital spot are in fact duplicated in the case of the intromittent organ, and that therefore not only is the evidence gained through the study of the first greatly strengthened, but the conclusions bearing on chromosome-theories are fully sustained on every point.

In the preliminary report of our results from the study of this second exclusively male character we gave what appear to us very cogent reasons for claiming that this character should be classed as a primary sexual character. Both Morgan ('13) and Doncaster ('14a\&'14b), in the case of the genital spot summarily dispose of our results and our claim that they have a valid bearing on the chromosome sex-determination hypothesis, by simply classing the genital spot with secondary sexual characters. Although there might be some ground for classing the genital spot with these characters, they are quite unlike in a most important feature, for a marked characteristic of the secondary sexual characters of authors is the fact that they can, almost without exception, be bred into the opposite sex. We do not believe that even these critics can thus dismiss the evidence obtained from a study of the transmission of the intromittent organ, although this evidence confirms in every detail the results demonstrated in the transmission of 
the genital spot. For convenience we repeat the argument from our preliminary report.

Both Morgan and Doncaster class the genital spot of variolarius with the secondary sexual characters of authors, and they therefore interpret our results as not having the bearing on the theories of sex-determination which we claim for them. Now our claim has been that the genital spot of variolarius is an integral part of the male genital segment-the structure of the female genital segment being such that the spot could not be present in this segment without ehanging the form of the segment itself-and we have claimed that therefore a study of the transmission of the genital spot should give a trustworthy indication of the method of transmission of the entire genital segment.

This claim, that the method of transmission of the genital spot should be an index of the method of transmission of the genital organs of the male, has been completely justified by further work on these hybrids... The genetic results from our study of the genital spot of variolarius may be open to the criticism that as the spot is "not directly connected with the act of reproduction" it should be classed with the secondary sexual characters; but the intromittent organ is certainly free from such criticism and can be justly classed as a primary sexual character. In view of the fact that our results from the study of the transmission of the variolarius spot have been set aside on the ground that the spot is a secondary sexual character, and therefore has no bearing on the problem of the determination of sex, it is necessary first to establish the claim that the intromittent organ can be classed with the primary and not the secondary sexual characters. This apparently ought not to be difficult, but a difficulty does arise owing to the fact that recent authors who have discussed secondary sexual characters have avoided defining them, and have neglected to state wherein they are to be distinguished from the primary sexual characters.

According to Darwin ('59) Hunter defines secondary sexual characters as follows :-

"The term, secondary sexual characters, used by Hunter, applies to characters which are attached to one sex; but are not directly connected with the act of reproduction."

Darwin ('86) adopts Hunter's classification of primary and secondary sexual characters, but shows that even such an apparently clear-cut definition encounters difficulties. He says * :- "With animals which have their sexes separated, the males necessarily differ from the females in their organs of reproduction; and these afford the primary sexual characters. But the sexes often differ in what Hunter has called secondary sexual characters, which are not directly connected with the act of reproduction; for instance, in

* The italics are ours. 
the male possessing certain organs of sense or locomotion, of which the female is quite destitute, or in having them more highly developed, in order that he may readily find or reach her; or again, in the male having special organs of prehension so as to hold her securely. These latter organs of infiuitely diversified kinds graduate into, and in some cases can hardly be distinguished from, those which are commonly ranked as primary, such as the complex appendages at the apex of the abdomen in male insects. Unless indeed we confine the term 'primary' to the reproductive glands, it is scarcely possible to decide, as far as the organs of prehension are concerned, which ought to be called primary and which secondary" (p. 253).

Morgan ('13) also appears to accept Hunter's classification, for in his rather full list of secondary sexual characters he includes none that are "directly connected with the act of reproduction." He opens his discussion of secondary sexual characters as follows :-

"The Secondary Sexual Characters.

"In the most highly evolved stages in the evolution of sex a new kind of character makes its appearance. This is the secondary sexual character. In most cases such characters are more elaborate in the male, but occasionally in the female. They are the most astonishing thing that nature has done: brilliant colours, plumes, combs, wattles, and spurs, scent-glands (pleasant and unpleasant); red spots, yellow spots, green spots, topknots and tails, horns, lanterns for the dark, songs, howlings, dances and tourneys - a medley of odds and ends" (p. 26).

If we are to discard Hunter's classification, because it is found difficult to determine to which class some of the characters rightly belong, we should have to be dissatisfied with many classifications that are thoroughly well established.

If we limit the term "primary sexual characters" to the reproductive glands, it offers an escape from the difficulties in classifying the prehensile organs, as Darwin has pointed out; but it would seem that greater difficulties are met by refusing to place the intromittent organ in the same group with the reproductive glands, and placing it in the group with characters so far removed from "direct connection with the act of reproduction", as, for example, Morgan's list of secondary sexual characters. The intromittent organ is not only "directly connected with the act of reproduction", but it is as much a part of the sex of the individual as the reproductive glands themselves. Any one of the characters in Morgan's entire list of male secondary sexual characters could appear in the female without changing her sex; but the intromittent organ is as clearly indicative of the sex as are the reproductive glands themselves.

If a definite chromosome carries the factors for determining sex, and it therefore carries the factors for the reproductive glands, it would seem logical to suppose that the chromosome carrying the factors necessary for 
the development of the male reproductive glands would also carry the factors necessary for the development of the intromittent organ which, when present, is functionally a necessary adjunct of the glands, and as indicative of the sex as the reproductive glands themselves. If we cannot accept the mode of transmission of the intromittent organ as an index of the mode of transmission of the reproductive glands, it would seem necessary to discard all structural features or other characters which are distinctive of the gonads of a given species, such as their distinction in size, form, colour, etc., and assume that these characters, associated with the gland, have a different mode of transmission from the gland itself.

This would prevent any experimental test being applied to the chromosometheories of sex-determination and leave free scope for the wildest cytological speculations. If we should place the intromittent organ in the group of secondary sexual characters, because it has certain features in common with these characters, we ought logically to place the reproductive glands themselves in the same group. For example, both these organs, in common with most of the secondary sexual characters, can be transmitted to the opposite sex-hermaphrodites appearing in forms that are normally sexually distinct A case in point is Goodrich's ('12) interesting and important discovery of a male amphioxus in which 49 of the gonads were testes containing ripe spermatozoa and one was an ovary containing ripe ova. It may be urged that the intromittent organ is a secondary sexual character on the evidence that in the development of the embryo it appears much later than do the gonads--this indicating that the gonads are more fundamental and stable morphological entities. But there are facts opposed to this interpretation-Smith ('10) found that when the spider crab is infected by the parasite sacculina, the testes can become so greatly metamorphosed that some of the cells may develop into ova and the same testis contain both ripe ova and spermatozoa.

It would seem that the division between primary and secondary sexual characters, in common with almost all attempts at classification, has the objection that the line of demarcation is not, at all points, perfectly clear; but we believe, in spite of this, that we are justified in classing the intromittent organ as a primary sexual character, and that the results from the study of the transmission of this organ may justly be claimed as an index of the method of transmission of the reproductive glands themselves.

In the case of the genital spot the bearing of our results on recent chromosome-theories has been fully discussed in our earlier papers. We believe we clearly demonstrated that the facts are entirely out of harmony with all those hypotheses which claim to offer an explanation of the transmission of characters by the assumption that factors essential to their transmission are carried and distributed by definite chromosomes. 
We have briefly summarized these results in a recent paper (Foot and Strobell, '14a), and this summary will serve equally well for the second exclusively male character-the intromittent organ. This can be demonstrated by quoting the summary and changing it only enough to include the intromittent organ with the genital spot, as follows :-

First. Both the genital spot and the type of intromittent organ characteristic of each species can be inherited without the aid of the $Y$ chromosome. This is proved by the fact that both are transmitted through the female, and the female does not possess the $\mathrm{Y}$ chromosome, as this chromosome is an exclusively male character.

Second. Both the genital spot and the type of intromittent organ can be inherited without the aid of the $\mathrm{X}$ chromosome. This is proved by the fact (demonstrated by the backcross) that they are transmitted through the male and ex hypothesi the male-producing spermatozoon does not have an $\mathrm{X}$ chromosome* .

We add, "In making these deductions it is, of course, necessary to accept, for the sake of the argument, the assumption of male- and female-producing: spermatozoa, an assumption which, we believe, is far from proved." (See backcross p. 473.)

1hird. The results show that if we assume that the factors necessary for the production of the genital spot and the intromittent organ are located in any of the ordinary chromosomes, they must be in at least both members of a pair of ordinary chromosomes, for the spot is directly transmitted through both the male and the female.

Fourth. The results show that, if we assume that the factors necessary for the production of the genital spot and the intromittent organ are carried by both members of a pair of chromosemes, we must assume that the female carries an inhibitor for the spot as well as for the intromittent organ, for neither is present in any of the females, though both are transmitted by the female, and therefore the factors for both are present, though not expressed.

Fifth. The results show that, although it is necessary to assume an inhibitor only in the females of the pure species, in the hybrids it becomes necessary to assume an inhibitor in the males also.

In his recent criticism of our work, Morgan ('14) overlooks the fact that the $\mathrm{F}_{1}$ hybrid males have the spot more or less suppressed. In these males it is partly or wholly absent, and yet (like the females) they can directly

* Morgan ('14) seems to think that this point could have been made solely from the evidence of the $\mathrm{F}_{2}$ ratio. He says: "It is unnecessary to repeat their argument; for if the factors were carried by the $\mathrm{X}$ chromosome only half the grandsons should show it, while, in fact, many more than half of them show it." We do not feel that this evidence would le conclusive, for it could be attacked by the assumption of an unequal death-rate-a convenient assumption which has been used more than once to excuse contradictory evidence. 
transmit the spot to their male offspring. It seems only logical to believe that the causes, whatever they are, which inhibit the spot in the females are also responsible for its total or partial suppression in the $\mathrm{F}_{1}$ hybrid males, but the causes suggested by our critics to account for its suppression in the females obviously cannot apply to the male hybrids. Morgan ('14), after admitting that the spot factors cannot be carried by the $\mathrm{X}$ or the $\mathrm{Y}$ chromosome, adds :- "We are concerned then only with a third possibility, viz. that there is something in the female condition itself that is inimical to the development of the spot." This something, he later explains, is the two $\mathrm{X}$ chromosomes. He says:- "The chemical interaction between two X's and the rest of the cell is of such kind that it produces a female, and the female complex, as such, is inimical to the development of a spot."

To the defenders of the chromosome-hypotheses, this may seem a plausible explanation of the suppression of the spot in the females which have these two $\mathrm{X}$ chromosomes, but it leaves unexplained the fact thai the spot in the $\mathrm{F}_{1}$ males is either wholly or partly suppressed, and these males have only one $\mathrm{X}$ chromosome, while two $\mathrm{X}$ chromosomes are held responsible for the suppression of the spot in the females.

The facts forced us to assume some sort of hypothetical inhibiting factors for the spot, not only for the females but for the $\mathrm{F}_{1}$ male hybrids as well, and this is equally necessary for the case of the intromittent organ, since it is not only wholly inhibited in the females, but the length of organ strictly characteristic of either of the pure species is more or less inhibited in the $\mathrm{F}_{1}$ hybrids. Further, the intromittent organ is like the spot in reappearing in the next generation in the length typical of the two parent species, proving this to have been latent in both the females and the $\mathrm{F}_{1}$ males-its full expression being inhibited by unknown factors.

Sixth. The facts show, in the case of the genital spot, and we may now add in the case of the intromittent organ as well, that if we attempt to place this inhibitor in definite chromosomes, we meet with as serious difficulties as those involved in assuming that the factors essential for the production of the genital spot are carried by special chromosomes. In our preliminary report of these experiments ('13), we discussed in full the evident results of placing this inhibitor in various chromosomes-in the $\mathrm{X}$ chromosomes, in one of the ordinary chromosomes, or in a pair of chromosomes; and we found that none of these assumptions would accord with the facts. "The facts force us to regard these inhibitors as hypothetical forces which cannot logically be confined to the chromosomes, and are located we know not where-these hypothetical inhibitors practically doing work that has been assigned to definite chromosomes."

If the chromosome-hypotheses have a foundation in fact, it would seem only logical to expect that in these insects the $\mathrm{Y}$ chromosome should carry the factors for exclusively male characters, for it is the only one of the 
14 chromosomes that is never present in the female, and is present in all the so-called male-producing spermatozoa, while each of the 13 autosomes. (according to their accepted mode of division) can be present in half the male-producing and half the female-producing spermatozoa, and therefore in both half the males and half the females.

Even the defenders of the chromosome sex-determination hypothesis reject: this $\mathrm{Y}$ chromosome as the carrier of factors essential for the determination of sex, for the very cogent reason that in so many forms no $\mathrm{Y}$ chromosome is present. Morgan ('11) concludes that "the factors for producing the male must be located in some other chromosome."

As the Y chromosome is thus rejected as a sex-determiner, it would seem that those who hold that factors essential for the development of definite characters are carried by definite chromosomes are forced to assign to the $\mathrm{Y}$ chromosome (in forms in which it is present) the function of carrying fuctors essential for the development of characters exclusively male, since, as stated above, it is the only chromosme that is always present in the male and absent in the female. We have shown, however, that such exclusively male characters as the genital spot and the intromittent organ can be inherited without the $\mathrm{Y}$ chromosome, and this certainly challenges such an interpretation, and leads us to respectfully ask the advocates of the chromosome-hypotheses what characters they would assign to it.

An ingenious apology for the obvious shortcomings of the sex-chromosome hypothesis has been recently made by C. B. Bridges, '13 (one of Morgan's pupils). It is offered as an explanation of occasional slips in linkage. Bridges found in Drosoplita ampelophila that two sex-linked characters (red eve and white eye) failed to show linkage in 5 per cent. of the cases (Wilson, '14, states that these exceptions are "about 10 per cent.").

To the class of cytologists to which Bridges belongs, "sex-linked characters" are in reality X-linked, and therefore, for example, it is theoretically impossible for a male to transnit directly to his male offspring a character that is assumed to be carried by the $\mathrm{X}$ chromosome-the chromosome that is absent from the male-producing spermatozoon. In order then to explain away these embarrassing slips in linkage, Bridges has submitted the following ingenious explanation, which is based on the admission that the $X$ chromsomes do not move during maturation with that military precision heretofore demanded by the theories. He now suggests each may show an equal amount of erratic movement-the one destined for the polar body may remain in the egg, and the one destined to remain in the egg may go with its mate to the polar body; and thus three kinds of ripe eggs are possible - the first with the usual one $\mathrm{X}$, the second with no $\mathrm{X}$ at all, and the third with two X's. This erratic behaviour of the X chromosomes can be made to account for many disappointments in expected results,. 
and incidentally it relieves the so-called male- and female-producing spermatozoa as such from the responsibility of deciding the sex, and places it squarely with the egg, for from a so-called male-producing spermatozoon a female can develop if this spermatozoon fertilizes an egg in which both $\mathrm{X}$ chromosomes have remained, and again from a so-called female-producing: spermatozoon a male can develop if this spermatozoon fertilizes an egg which has no $\mathrm{X}$ chromosome.*

It is naturally incumbent upon the cytologist who makes assumptions so necessary for the defence of a theory to find some cytological proof of them, and Wilson ('14) has made the interesting announcement that "very recently Bridges has tested his assumption cytologically". And he adds, "The cytological examination has demonstrated that certain females of this race actually possess three of these chromosomes."

Wilson seems to regard this evidence as quite conclusive proof of Bridges' assumptions and deductions. Those of us, however, who have no sucin sublime faith in the causal nature of the chromosomes are inclined to suspect that if Bridges had searched with equal ardour for an extra $\mathrm{X}$ chromosome in the male cells, he might have found these cells also equipped with an extra $\mathrm{X}$ chromosome, as in fact we found to be the case in the spermatogonia of Anasa tristis (Foot and Strobell, '07). In spite of our demonstrating this second $\mathrm{X}$ chromosome by photomicrographs, the reality of its presence has been questioned by advocates of the chromosome-theories, for it is obviously an embarrassing factor to the sex-determination hypothesis.

Further study of the chromosomes of the Hemiptera led us to make the following statement which seems to us to have some bearing on Bridges' recent discovery :- "A careful examination of our preparations makes it possible to select chromosome-groups which exactly fit a given theory, but many groups can also be found that are a serious menace to these theories, while, on the other hand, they present no difficulties to the conception of those who regard the number, size, and form of the chromosomes as inherited characters-the expression of cell-activities rather than the cause."

In our preliminary report (Foot and Strobell, '14c, pp. 228-31) we showed by an anslysis of the chromosomes, based on the hypotheses as to their method of division, that the testis itself can have no closer relation to the so-called sex-determining chromosomes than we have shown to be the case

* Bridges' assumptions, when applied to those forms which have a Y chromosome, would seem to relieve this chromosome of any sex-limited function, although in these species it is just as distinctive of the male cells as are the two $\mathrm{X}$ chromosomes of the female cells. According to Bridges' hypothesis, some males may be without the Y chromosome, while some females have it. The admission that such marked structural changes in the male and female chromosome groups can occur in individuals is in harmony with the belief that the chromosomes, like other structures in the cell, are the expression rather than the cause of cell activities. 
for the other two exclusively male characters-the genital spot and the intromittent organ. These three exclusively male characters-the genital spot, the intromittent organ, and the testis-can therefore, according to the hypothesis, be transmitted by the female-producing spermatozoon as well as. by the male-producing spermatozoon.

The defenders of the chromosome-hypothesis of sex-determination would have us ignore these facts. Morgan ('14) says:- "To assume that all the factors for characters that are shown by the male or by the female must be carried by a sex-chromosome of some kind, if carried at all by chromosomes, is a travesty of the point of view of those who hold to the chromosomehypothesis as a reasonable working hypothesis to account for Mendelian inheritance." This sounds like an effort to evade the force of the real facts. It should be added that two of these "characters" (the intromittent organ and the testis) are so exclusively male that without them the insect would not be a male, and to present these facts and the conclusions which they logically involve can scarcely be called "a travesty" of the hypothesis. that asserts that factors determining sex are carried and distributed by "sex-chromosomes." Rather it is a serious and perfectly logical challenge of some recent extreme views as to the function of the chromosomes in heredity.

Oxford, March 1915.

\section{References.}

Bridges, Calvin B.

'13. Non-disjunction of the Sex Chromosomes of Drosophila. Journ. Exper. Zool. vol. xv. No. 4.

Castle, W. E.

'11. Heredity in Relation to Evolution and Animal Breeding. D. Appleton \& Company. 1911.

'12a. The The Inconstancy of Unit-characters. Amer. Nat. vol. xlvi.

'12 b. Some Biological Principles of Animal Breeding. A mer. Breeders' Magazine, vol. iii. No. 4.

'14 a. Multiple Factors in Heredity. Science, n. s. vol. xxxix.

'14b. Pure Lines and Selection. Journ. of Heredity (Organ of the Amer. Genetic Assoc.), Washington, D.C., vol. v. No. 3.

Castle, W. E., and John C. Phillips.

'14 c. Piebald Rats and Selection. An experimental test of the effectiveness of selection and of the theory of gametic purity in Mendelian crosses. Carnegie Institution of Washington, 1914.

Darwin, Charles Robert.

'59. The Origin of Species. 1859.

'86. The Descent of Man. 1886. 
Doncaster, Lemonard.

'14a. Heredity and Sex-A Review of the Present State of Evidence. with regard to the material basis of Heredity, Transmission, and Sex-determination. Q. J. M. Sci. vol. liv.

'14 $b$. The Determination of Sex. Cambridge University Press. Foot, Katharine, and E. C. Strobell.

'07. A Study of Chromosomes in the Spermatogenesis of Anasa tristis. Amer. Journ. Anat. vol. vii. No. 2.

'09. The Nucleoli in the Spermatocytes and Germinal Vesicles of Euschistus variolarius. Biol. Bull. vol, xvi. No. 5.

'13. Preliminary Note on the Results of crossing two Hemipterous. Species, with Reference to the Inheritance of an Exclusively Male Character and its bearing on Modern Chromosome Theories. Biol. Bull, vol. xxiv. No. 3.

'14a. Results of crossing Euschistus variolarius and Euschistus servus. with Reference to the Inheritance of an Exclusively Male Character. Journ. Linn. Soc. London, Zool. vol, xxxii.

'14b. The Chromosomes of Euschistus variolarius, Euschistus servus, and the Hybrids of the $\mathrm{F}_{1}$ and $\mathrm{F}_{2}$ Generations. Arch. für Zellf., Bd. 12.

'14c. Preliminary Report of crossing two Hemipterous Species with Reference to the Inheritance of a Second Exclusively Male Character. Biol. Bull. vol. xxvii. No. 4.

Goodrich, Edwin Stephen.

'12. A Case of Hermaphroditism in Amphioxus. Anat. Anz., Bd. 42. Morgan, Thomas Hunt.

'11. An Attempt to Analyse the Constitution of the Chromosomes on the Basis of Sex-limited Inheritance in Drosophila. Journ. Exp. Zool. vol. xi. No. 4.

'13. Heredity and Sex. Columbia University Press. 1913.

'14. Sex-limited and Sex-linked Inheritance. Amer. Nat. vel. xlviii. Suith, Geoffrey Watkin.

'10. Studies in the Experimental Analysis of Sex. Q. J. M. Sci. vol. lv. pt. 2.

Wilson, Edmund Beecher.

'14. Croonian Lecture. Proc. Royal Soc., ser. B, vol. Ixxxviii. No. B 603 . 


\section{EXPLANATION OF THE PLATES.}

All the preparations were photographed at exactly the same magnification (20 diameters), and the photograph of each intromittent organ was carefully measured with a small pair of architect's dividers, fitted with number nine needle-points, and set at $2 \mathrm{~mm}$. The dividers were frequently tested by measuring a line of a definite length. The measurements were made on matte prints, so that each division of $20 \mathrm{~mm}$. could be identified by a pencil-mark and numbered. Measurement of the longer and more closely coiled organs was facilitated by dotting the first coil with red ink, the second coil with blue ink, and leaving the third coil black. In this way the longest coil could then be measured with as much accuracy as the shortest. The measurements were made from the distal end of the intromittent organ to the point where the thick part of the coil enters the gland. At this point the coil is easily dissected off (e.y., photos 12 \& 13), but even in those cases where part of the canal within the gland has been preserved (e.g., photo 1 ) the point from which the measurement was taken is easily determined, for the part within the gland is transparent and quickly tapers to a very fine canal.

The intromittent organs of photos 1 to 66 are from the same insects which were photographed in an earlier paper and published in this same volume of the Journ. Linn. Soc., Zool. (see Plates 28 to 34 ).

In order to demonstrate whether these two exclusively male characters--the genital spot and the intromittent organ-are linked in inheritance, we have placed the intromittent organs of photos 1 to 66 in exactly the same order in which the photographs of the bugs themselves were placed on the plates of the above-mentioned paper-each photograph in the two sets of illustrations exactly corresponding, and thus admitting an accurate comparison of the genital spot and the intromittent organ of each individual bug of the entire series.

The photographs are reproduced by the half-tone method. Frequestly it does not accurately reproduce the distal end of the intromittent organs, which always terminate in a clean-cut oblique angle: this is sometimes obscured by the dotted effect of the half-tone method, giving the appearance of a broken, jagged end. In some cases the reproducers have attempted to correct this by retouching; but this has not always been successful.

\section{Plate: 41.}

(Cf. Plate 28 of this volume.)

Рното 1. Intromittent organs from the two bugs of photo 1, plate 28. On the left $E$. variolarius, and on the right $E$. servus. Length of intromittent organ of E. variolarius $95 \mathrm{~mm}$., of $E$. servus $167 \mathrm{~mm}$.

Рното 2. Intromittent organs from the seven E. variolarius of photo 2, plate 28. These insects were raised in our laboratory during the summer of 1912. The parent bugs were raised in our laboratory during the summer of 1911, and were kept in captivity during the winter of 1911-12. Lengths of the intromittent organs of the seven bugs are as follows:-1st (upper), $96 \mathrm{~mm}$. 2nd, $101 \mathrm{~mm}$. 3rd, $96 \mathrm{~mm}$. 4th, $93 \mathrm{~mm}$. 5th, $90 \mathrm{~mm}$. 6th, $96 \mathrm{~mm}$. 7th, $92 \mathrm{~mm}$.

Рното 3. Intromittent organs from the five E. servus of photo 3, plate 28. The bugs were collected in North Carolina in the fall of 1912. Lengths of the intro-

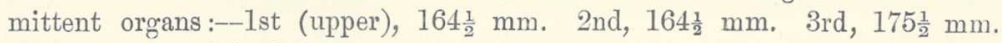
4th, $166 \mathrm{~mm}$. 5th, $170 \mathrm{~mm}$.

Рното 4. Intromittent organ of the wild E. servus of photo 4, plate 28. This male fertilized the E. variolarius female used for our cross-breeding experiments. Length of intromittent organ, $166 \mathrm{~mm}$. 
Proto 5. Intromittent organs of the five E. servas that were caged during the winter of 1911-12 with three $E$. variolarius females, one of which was used for our cross-breeding experiments. (The last three of these five males are shown in photo 5, plate 28.) Lengths of the intromittent organs:--1st (upper), $161 \mathrm{~mm}$. 2nd, $162 \mathrm{~mm}$. 3rd, $166 \mathrm{~mm}$. 4th, $146 \mathrm{~mm}$. 5th, $169 \mathrm{~mm}$.

Рното 6. Intromittent organs from two E. variolarius. These males were raised from the same deposition of eggs from which we raised the females for our crossbreeding experiments. Only one of these males (the 2nd) is shown in photo 5, plate 28. Lengths of the intromittent organs:-1st (upper), $104 \mathrm{~mm} .2$ 2nd, $94 \mathrm{~mm}$.

Рното 7. Intromittent organs from the two $\mathrm{F}_{1}$ hybrids of photo 7 , plate 28 . Lengthe of the intromittent organs :--1st (upper), $126 \mathrm{~mm}$. 2nd, $124 \mathrm{~mm}$.

Рното 8. Intromittent organs from the two $F_{1}$ hybrids of photo 8 , plate 28. Lengths of the intromittent organs:-] st (upper), $126 \mathrm{~mm}$. 2nd, $124 \mathrm{~mm}$.

Рното 9. Intromittent organ from the one $\mathrm{F}_{1}$ hybrid that was preserved as a pinned specimen. This is the only intromittent organ that cannot be compared with a photograph of the insect from which it was dissected. The intromittent organ of the insect of photo 9, plate 28 , was broken in dissection, and we therefore replaced it with this organ from the dried specimen. Length, $126 \mathrm{~mm}$.

Рното 10. Intromittent organ of the $\mathrm{F}_{1}$ hybrid of photo 10, plate 28. Length of intromittent organ, $109 \mathrm{~mm}$. (This includes $3 \mathrm{~mm}$. for the extreme distal end that was broken off in dissection and not preserved.) This hybrid is the male rarent of the $\mathrm{F}_{2}$ hybrids of plate 31 .

Рното 11. Intromittent organ of the $F_{1}$ hybrid of photo 11, plate 28. Length of intromittent organ, $134 \mathrm{~mm}$.

This hybrid is the male parent of the $\mathrm{F}_{2}$ hybrids of photos 15 and 16 , plate 28.

Рното 12. Intromittent organ of the $\mathrm{F}_{1}$ hybrid of photo 12, plate 28. Length of intromittent organ, $132 \mathrm{~mm}$.

This hybrid is the male parent of the $F_{2}$ hybrids of photos 42 to 48 , plate 32 .

Рното 13. Intromittent organ of the $\mathrm{F}_{1}$ hybrid of photo 13, plate 28. Length of intromittent organ, $122 \mathrm{~mm}$.

This male fertilized the two $F_{1}$ females of the 6th and 7 th pairs of $F_{1}$ hybrids, and is therefore the male parent of the $\mathrm{F}_{2}$ hybrids of photos 49 to 57 , plates $32 \& 33$.

Pното 14. Intromittent organ of the $F_{1}$ hybrid of photo 14, plate 28. Length of intromittent organ, $126 \mathrm{~mm}$.

This hybrid is the male parent of the $\mathrm{F}_{2}$ hybrids of photos 26 to 32, plate 30 .

Pнотоs 15 \& 16 . Intromittent organs from the four $F_{2}$ males from the fifth pair of $F_{1}$ hybrids.

Рното 15. Intromittent organs of the three $F_{2}$ hybrids of photo 15, plate 28. Length of intromittent organs:-1st (upper), $108 \mathrm{~mm}$. 2nd, $107 \frac{1}{2} \mathrm{~mm}$. $3 \mathrm{rd}, 147 \mathrm{~mm}$.

Рното 16. Intromittent organ of the $\mathrm{F}_{2}$ hybrid of photo 16, plate 28. Length of intromittent organ, $135 \mathrm{~mm}$. (See photo 11 for the intromittent organ of the male parent of the four $\mathrm{F}_{2}$ hybrids of photos 15 and 16.) 
Plate 42.

(Cf. Plate 29 of this rolume.)

The intromittent organs from $43 \mathrm{~F}_{2}$ males from the first pair of $\mathrm{F}_{1}$ hybrids. The male parent of these hybrids is shown in photo 9 , plate 28 , but we did not succeed in preserving its intromittent organ (see photo 9 ).

Рното 17. Intromittent organs from the five $F_{2}$ hybrids of photo 17, plate 29. Lengths of intromittent organs:--1st (upper), $96 \mathrm{~mm}$. 2nd, $146 \mathrm{~mm}$. 3rd, $130 \mathrm{~mm}$. 4 th, $136 \mathrm{~mm}$. 5th, $150 \mathrm{~mm}$.

Рното 18. Intromittent organs from the five $\mathrm{F}_{2}$ hybrids of photo 18 , plate 29. Lengths of intromittent organs :-1st (upper), $112 \frac{1}{2} \mathrm{~mm}$. 2nd, $128 \mathrm{~mm}$. 3rd, $122 \mathrm{~mm}$. 4th, $137 \mathrm{~mm}$. 5th, $148 \mathrm{~mm}$.

Рното 19. Intromittent organs of the four $\mathrm{F}_{2}$ hybrids of photo 19, plate 29. Lengths of intromittent organs:-1st (upper), $114 \mathrm{~mm}$. 2nd, $129 \mathrm{~mm}$. 3rd, $139 \frac{1}{2} \mathrm{~mm}$. 4 th, $144 \mathrm{~mm}$.

Рното 20. Intromittent organs of the three $\mathrm{F}_{2}$ hybrids of photo 20, plate 29. Lengths of intromittent organs :-1st (upper), $130 \mathrm{~mm}$. 2nd, $120 \mathrm{~mm}$. 3rd, $98 \mathrm{~mm}$.

Рното 21. Intromittent organs of the six $\mathrm{F}_{2}$ hybrids of photo 21, plate 29. Lengths of intromittent organs:-1st (upper), $124 \mathrm{~mm} .2 \mathrm{nd}, 152 \mathrm{~mm}$. 3rd, $133 \mathrm{~mm}$. $4 \mathrm{th}, 122 \mathrm{~mm}$. 5 th, $136 \mathrm{~mm}$. 6th, $97 \mathrm{~mm}$.

Рното 22. Intromittent organs of the five $\mathrm{F}_{2}$ hybrids of photo 22, plate 29. Lengths of intromittent organs:-1st-(upper), $136 \mathrm{~mm}$. 2nd, $146 \mathrm{~mm}$. 3rd, $124 \mathrm{~mm}$. $4 \mathrm{th}, 128 \frac{1}{2} \mathrm{~mm}$. 5th, $130 \mathrm{~mm}$.

Рното 23. Intromittent organs of the four $\mathrm{F}_{2}$ hybrids of photo 23, plate 29. Lengths of intromittent organs :-1st (upper), $98 \mathrm{~mm}$. 2nd, $120 \mathrm{~mm}$. 3rd, $104 \mathrm{~mm}$. 4 th, $122 \mathrm{~mm}$.

Рното 24. Intromittent organs of the three $\mathrm{F}_{2}$ hybrids of photo 24, plate 29. Lengths of intromittent organs : -1 st (upper), $100 \mathrm{~mm}$. 2nd, $114 \mathrm{~mm}$. 3rd, $132 \frac{1}{2} \mathrm{~mm}$.

Рното 25. Intromittent organs of the eight $\mathrm{F}_{2}$ hybrids of photo 25, plate 29. Lengths of

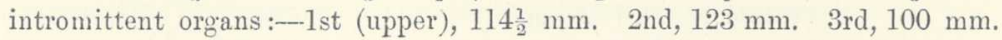
4th, $108 \mathrm{~mm}$. 5th, $93 \mathrm{~mm}$. 6th, $132 \mathrm{~mm}$. 7th, $85 \frac{1}{2} \mathrm{~mm}$. 8th, $140 \mathrm{~mm}$.

\section{Plate 43.}

(Cf. Plate 30 of this volume.)

Intrumittent organs from $30 \mathrm{~F}_{2}$ males, from the second pair of $\mathrm{F}_{1}$ hybrids. The male parent of these hybrids is shown in photo 14 , plate 28 , and its intromittent organ in photo 14, Plate 41.

Рното 26. Intromittent organs from the five bug's of photo 26, plate 30. Lengths of intromittent organs:-1st (upper), $115 \frac{1}{2} \mathrm{~mm}$. 2nd, $100 \mathrm{~mm}$. 3rd, $116 \mathrm{~mm}$. 4th, $118 \mathrm{~mm}$. 5th, $118 \mathrm{~mm}$.

Рното 27. Intromittent organs from the four bugs of photo 27, plate 30. Lengths of intromittent organs :-1st (upper), $99 \mathrm{~mm}$. (this includes $3 \mathrm{~mm}$. for the extreme distal end that was broken off in dissection and not preserred). 2nd, $130 \mathrm{~mm}$. 3rd, $130 \mathrm{~mm}$. 4th, $130 \mathrm{~mm}$.

Рното 28. Intromittent organs from the six bugs of photo 28, plate 30. Lengths of intromittent organs:-1st (upper), $90 \mathrm{~mm}$. 2nd, $142 \mathrm{~mm}$. 3rd, $124 \mathrm{~mm}$. 4th, $131 \mathrm{~mm}$. 5th, $121 \mathrm{~mm}$. 6th, $127 \frac{1}{2} \mathrm{~mm}$.

Рното 29. Intromittent organs from the five bugs of photo 29, plate 30. Lengths of intromittent organs:- - lst (upper), $124 \mathrm{~mm}$. 2nd, $123 \mathrm{~mm}$. 3rd, $125 \mathrm{~mm}$. 4 th, $126 \mathrm{~mm}$. 5th, $126 \mathrm{~mm}$. 
Pното 30. Intromittent organs from the four bugs of photo 30, plate 30. Lengths of intromittent organs:-1st (upper), $130 \mathrm{~mm}$. 2nd, $134 \frac{1}{2} \mathrm{~mm}$. $3 \mathrm{rd}, 115 \frac{1}{2} \mathrm{~mm}$. 4th, $133 \mathrm{~mm}$. (this includes $3 \mathrm{~mm}$. for the extreme distal end that was broken off in dissection and not preserved).

Рното 31. Intromittent organs from the three bugs of photo 31, plate 30. Lengtlis of intromittent organs :-1st (upper), $114 \mathrm{~mm}$. 2nd, $114 \mathrm{~mm}$. 3rd, $99 \frac{1}{2} \mathrm{~mm}$.

Рното 32. Intromittent organs from the three bugs of photo 32, plate 30. Lengths of intromittent organs:-1st (upper), $114 \frac{1}{2} \mathrm{~mm}$. 2nd, $122 \mathrm{~mm}$. $\quad 3 \mathrm{rd}, 127 \mathrm{~mm}$.

\section{Plate 44.}

(Cf. Plate 31 of this volume.)

Intromittent organs from $48 \mathrm{~F}_{2}$ males from the third pair of $F_{1}$ hybrids. The male parent of these hybrids is shown in photo 10 , plate 23 , and its intromittent organ in photo 10, Plate 41.

Рното 33. Intromittent organs from the six bugs of photo 33, plate 31. Lengths of intromittent organs :- 1 st (upper), $117 \frac{1}{2} \mathrm{~mm} . \quad 2 n d, 124 \mathrm{~mm}$. $3 \mathrm{rd}, 116 \frac{1}{2} \mathrm{~mm}$.

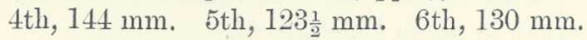

Рното 34. Intromittent organs from the eight bugs of photo 34, plate 31. Lengths of intromittent organs:-1st (upper), $128 \mathrm{~mm}$. 2nd, $131 \mathrm{~mm}$. 3rd, $140 \mathrm{~mm}$. 4th, $130 \mathrm{~mm}$. 5th, $140 \mathrm{~mm}$. 6th, $121 \mathrm{~mm}$. 7th, $123 \mathrm{~mm}$. 8th, $147 \mathrm{~mm}$.

Рното 35. Intromittent organs from the five bugs of photo 35, plate 31. Lengths of intromittent organs :-ist (upper), $104 \mathrm{~mm}$. 'nd, $115 \mathrm{~mm}$. 3rd, $126 \mathrm{~mm}$. 4th, $134 \mathrm{~mm}$. 5th, $134 \frac{1}{2} \mathrm{~mm}$.

Рното 36. Intromittent organs from the seren bugs of photo 36 , plate 31. Lengths of intromittent organs :-1st (upper), $114 \mathrm{~mm}$. 2nd, $127 \frac{1}{2} \mathrm{~mm}$. 3rd, $127 \frac{1}{2} \mathrm{~mm}$. 4th, $124 \mathrm{~mm}$. 5th, $142 \mathrm{~mm}$. 6th, $120 \mathrm{~mm}$. 7th, $127 \frac{1}{2} \mathrm{~mm}$.

Рното 37. Intromittent organs from the three bugs of photo 37, plate 31. Lengths of

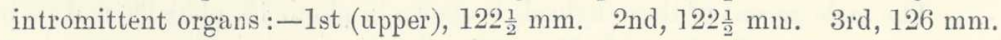

Рното 38. Intromittent organs from the five bugs of photo 38, plate 31. Lengths of intromittent organs :- - 1st (upper), $112 \mathrm{~mm}$. 2nd, $120 \mathrm{~mm}$. 3rd, $126 \mathrm{~mm}$. 4th, $139 \frac{1}{2} \mathrm{~mm}$. 5th, $140 \mathrm{~mm}$.

Рното 39. Intromittent organs from the four bugs of photo 39, plate 31. Lengths of intromittent organs :- 1 st (upper), $137 \mathrm{~mm}$. 2nd, $134 \frac{1}{2} \mathrm{~mm}$. 3rd, $140 \mathrm{~mm}$. 4 th, $124 \mathrm{~mm}$.

Рното 40. Intromittent organs from the seren bugs of photo 40, plate 31. Lengths of intromittent organs:-1st (upper), $114 \frac{1}{2} \mathrm{~mm}$. 2nd, $117 \mathrm{~mm}$. 3rd, $122 \mathrm{~mm}$. 4th, $136 \frac{1}{2} \mathrm{~mm}$. 5th, $126 \mathrm{mn}$. 6th, $126 \frac{1}{2} \mathrm{~mm}$. 7 th, $120 \mathrm{~mm}$.

Рното 41. Intromittent organs from the three bugs of photo 41, plate 31. Lengths of intromittent organs :-1st (upper), 116 $\frac{1}{2} \mathrm{~mm}, 2 \mathrm{nd}, 132 \mathrm{~mm}$. 3rd, $126 \mathrm{~mm}$.

\section{Plate 45.}

\section{(Cf. Plate $\mathbf{3 2}$ of this volume.)}

Photos 42-48. Intromittent organs from the $27 \mathrm{~F}_{2}$ males from the fourth pair of $\mathrm{F}_{1}$ hybrids. The male parent of these hybrids is shown in photo 12, plate 28, and its intromittent organ in photo 12 , Plate $\mathbf{4 1 .}$

Рното 42. Intromittent organs from the four bug's of photo 42, plate 32. Lengths

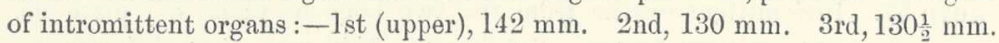
4th, $136 \mathrm{~mm}$. 
Pното 43. Intromittent organs from the seven bugs of photo 43, plate 32. Lengths of iutromittent organs : - 1st (upper), $118 \frac{1}{2} \mathrm{~mm}, 2 \mathrm{nd}, 132 \mathrm{~mm}, \quad 3 \mathrm{rd}, 140 \mathrm{~mm}$. 4 th, $133 \mathrm{~mm} . \quad 5 \mathrm{th}, 127 \mathrm{~mm}$. 6th, $138 \mathrm{~mm} . \quad 7$ th, $141 \frac{1}{2} \mathrm{~mm}$.

Рното 44. Intromittent organs from the two bugs of photo 44, plate 32 . Lengths of intronittent organs:-1st (upper), $115 \mathrm{~mm}$. 2nd, $127 \mathrm{~mm}$.

Рното 45. Intromittent organs frim the three buys of photo 45 , plate 32 . Lengths of intromittent organs :-1st (upper), $128 \mathrm{~mm}$. 2nd, $136 \mathrm{~mm} .3 \mathrm{rd}$, $137 \mathrm{~mm}$.

Рното 46. Intromittent organs from the six bugs of photo 46, plate 32 . Lengths of intromittent organs :- - 1st (upper), $116 \frac{1}{2} \mathrm{~mm}$. 2nd, $128 \mathrm{~mm}$. 3rd, $122 \mathrm{~mm}$. 4 th, $120 \mathrm{~mm}$. 5th, $136 \mathrm{~mm}$. 6th, $127 \mathrm{~mm}$.

Рното 47. Intromittent organs from the four bugs of photo 47 , plate 32 . Lengths of intromittent organs:- - 1st (upper), $119 \frac{1}{2} \mathrm{~mm}$. 2nd, $110 \mathrm{~mm}$. 3rd, $142 \mathrm{~mm}$. 4 th, $121 \mathrm{~mm}$.

Рното 48. Intromittent organ frum the male of photo 48, plate 32. Length of intromittest organ, $110 \mathrm{~mm}$.

Pнотоs 49 \& 50. Intromittent organs from the six $\mathrm{F}_{2}$ males from the sixth pair of $\mathrm{F}_{t}$ hybrids. The male parent of these hrbrids is shown in photo 13, plate 28, and its intromittent organ in photo $13, \mathrm{Pl}$ ate $\mathbf{4 1 .}$

Рното 49. Intromittent organs from the two bugs of photo 49, plate 32.

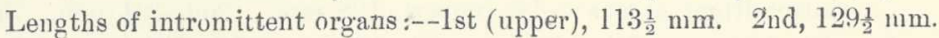

Рното 50. Intromit'x Lengths of intron.i:t mnt organs:-1st (upper), $128 \mathrm{~mm}$. 2ud, $128 \mathrm{~mm} .3 \mathrm{rd}$, $125 \mathrm{~mm}$. 4th, $13.4 \mathrm{~mm}$.

\section{Plate 46.}

\section{(Cf. Plate $\mathbf{3} 3$ of this volume.)}

Intromittent organs from $32 \mathrm{~F}_{2}$ males from the seventh pair of $\mathrm{F}_{1}$ hybrids.

The male parent of these hybrids is shown in photo 13 , plate 28 , aud its intro-

mittent organ in photo 13, Plate $4 \mathbf{1}$.

Рното 51. Intromittent organs from the nine bugs of photo 51, plate 33. Lengths of intromittent organs:-1st (upper), $110 \mathrm{~mm}$. 2nd, $120 \mathrm{~mm}$. $8 \mathrm{rd}, 131 \mathrm{~mm}$. 4th, $119 \mathrm{~mm}$. 5th, $136 \frac{1}{2} \mathrm{~mm}$. 6th, $121 \frac{1}{2} \mathrm{~mm} . \quad 7$ th, $138 \mathrm{~mm} . \quad 8 \mathrm{th}, 115 \mathrm{~mm}$. $9 \mathrm{th}, 122 \mathrm{~mm}$.

Рното 52. Intromittent organs from the six bugs of photo 52, plate 33. Lengths of intromittent organs :- - 1st (upper), $127 \mathrm{~mm}$. 2nd, $123 \frac{1}{2} \mathrm{~mm}$. 3rd, $112 \mathrm{~mm}$. 4th, $128 \mathrm{~mm}$. 5th, $120 \mathrm{~mm}$. 6th, $136 \mathrm{~mm}$.

Рното 53. Intromittent organs from the four bugs of photo 53, plate 33. Lergths of intromittent organs:-1st (upper), $115_{\frac{1}{2}} \mathrm{~mm}$. 2nd, $112 \mathrm{~mm}$. $3 \mathrm{rd}, 115 \mathrm{~mm}$. 4 th, $143 \frac{1}{2} \mathrm{~mm}$.

Рното 54. Intromittent organs from the four bugs of photo 54, plate 33. Lengths of intromittent organs:-1st (upper), $130 \mathrm{~mm}$. 2nd, $120 \mathrm{~mm}$. $3 \mathrm{rd}, 135 \mathrm{~mm}$. 4 th, $112 \mathrm{~mm}$.

Рното 55. Intromittent organs from the four bugs of photo 55, plate 33. Lengths of intromittent organs:--1st (upper), $116 \frac{1}{2} \mathrm{~mm}$. 2nd, $118 \mathrm{nmm}$. 3rd, $118 \mathrm{~mm}$. $4 \mathrm{th}, 131 \mathrm{~mm}$.

Рното 56. Intromittent organs from the three bigs of photo 56, plate 33. Lengths of intromittent organs :-1st (upper), $112 \frac{1}{2} \mathrm{~mm}$. 2nd, $119 \mathrm{~mm}$. 3rd, $129 \frac{1}{2} \mathrm{~mm}$.

Рното 57. Intromittent organs from the two bugs of photo 57, plate 33. Lengtlis of intromittent organs $-1 \mathrm{st}$ (upper), $106 \frac{1}{2} \mathrm{~mm}$. 2nd, 120 $\mathrm{mm}$. 


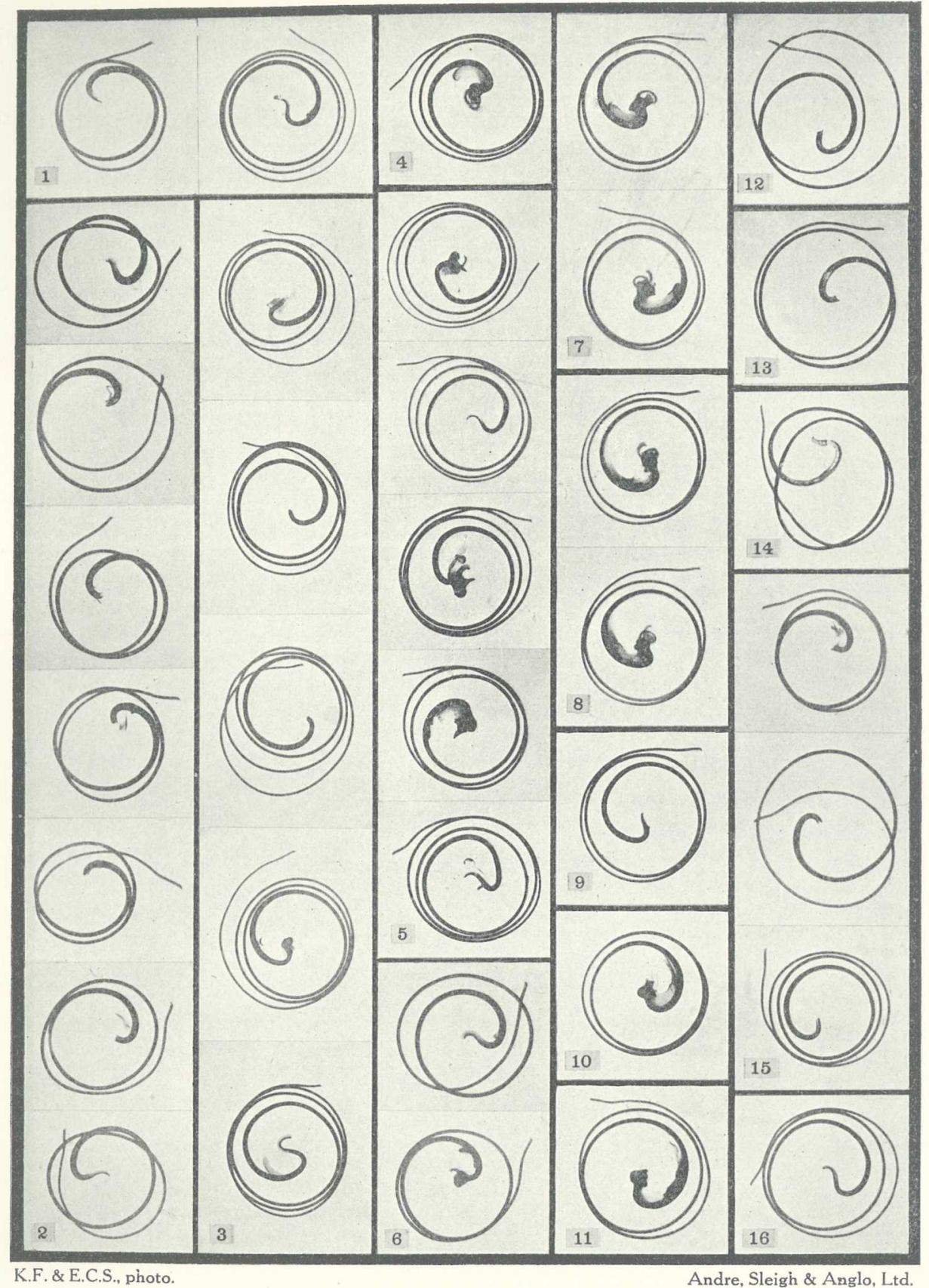

INTROMITTENT ORGANS from EUSCHISTUS VARIOLARIUS, E. SERVUS, \& HYBRIDS. 


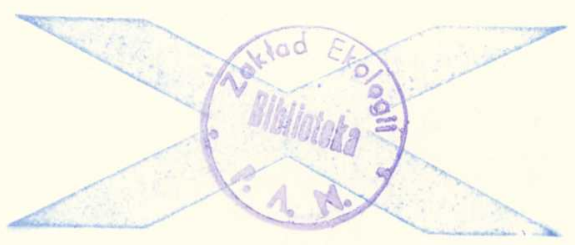

rcin.org.pl 


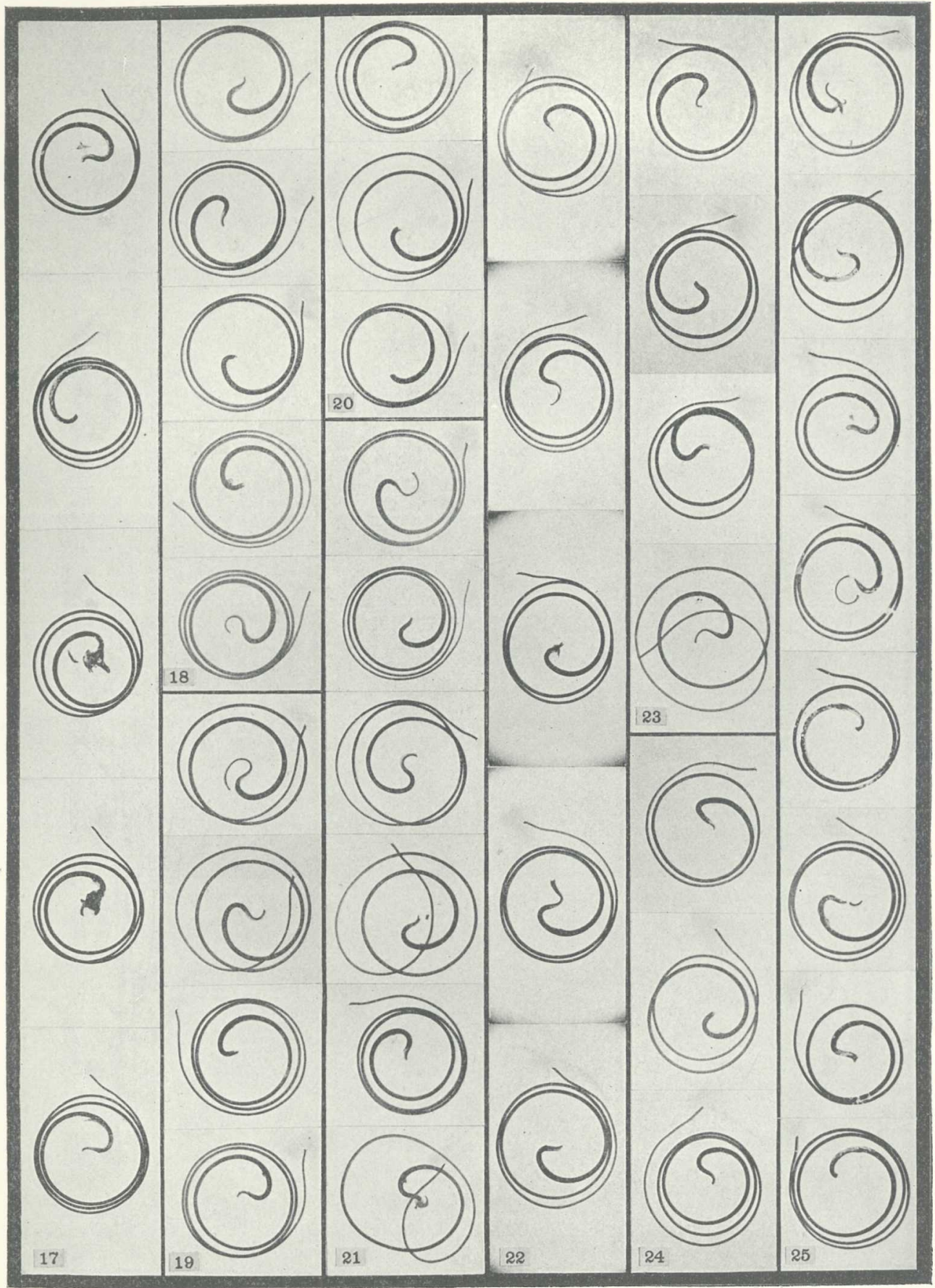

K.F. \& E.C.S., photo.

Andre, Sleigh \& Anglo, Ltd.

INTROMITTENT ORGANS from $F_{2}$ HYBRIDS from E. VARIOLARIUS \& E. SERVUS. 


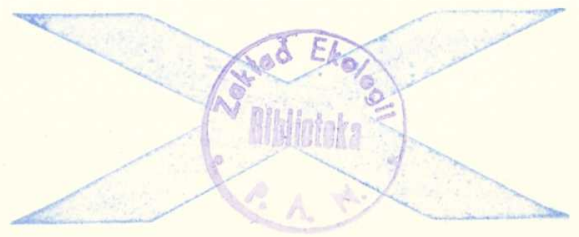

rcin.org.pl 


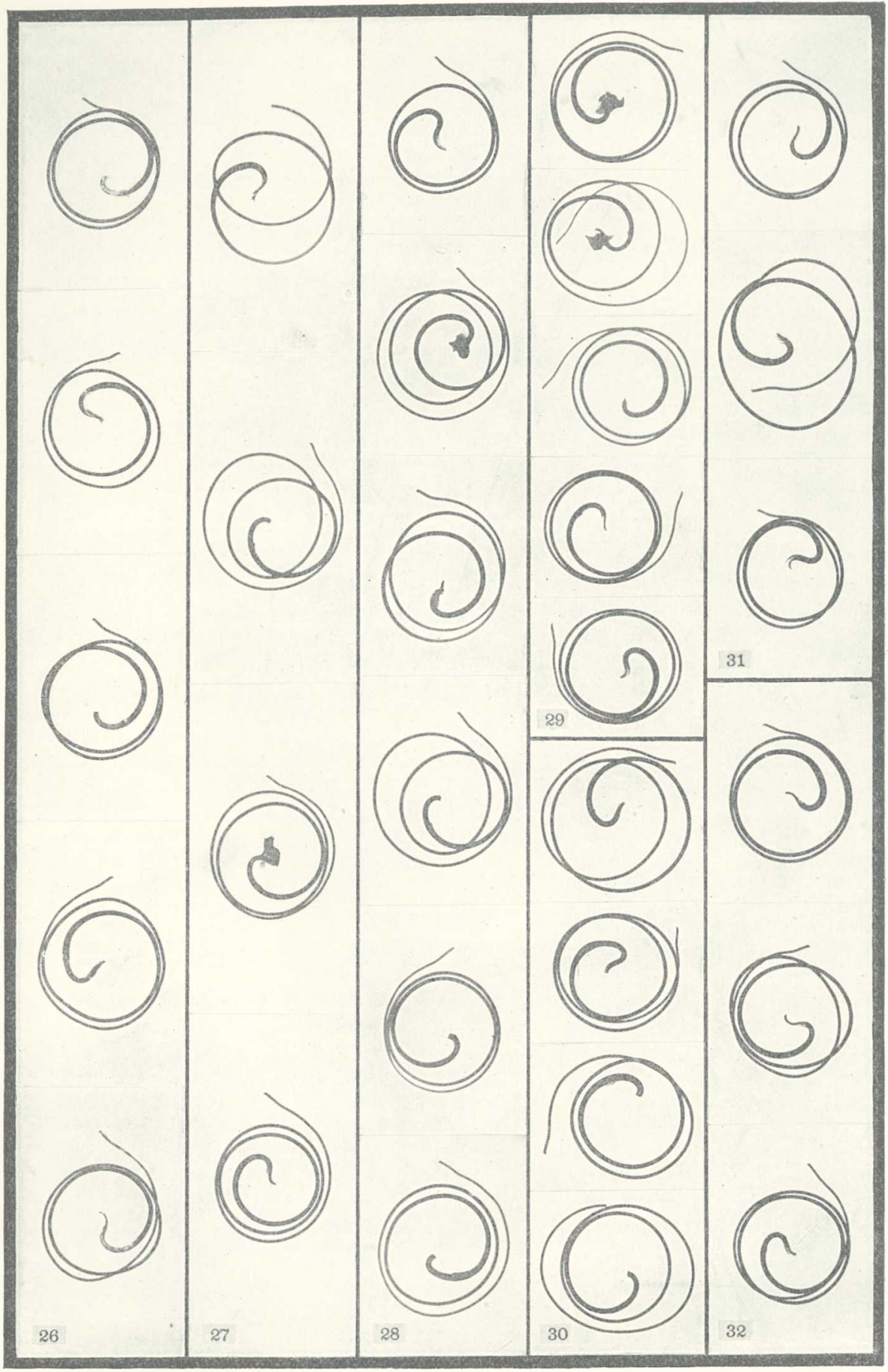




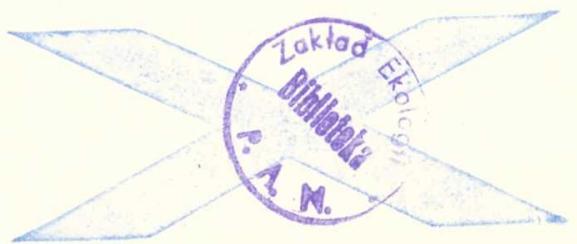

rcin.org.pl 


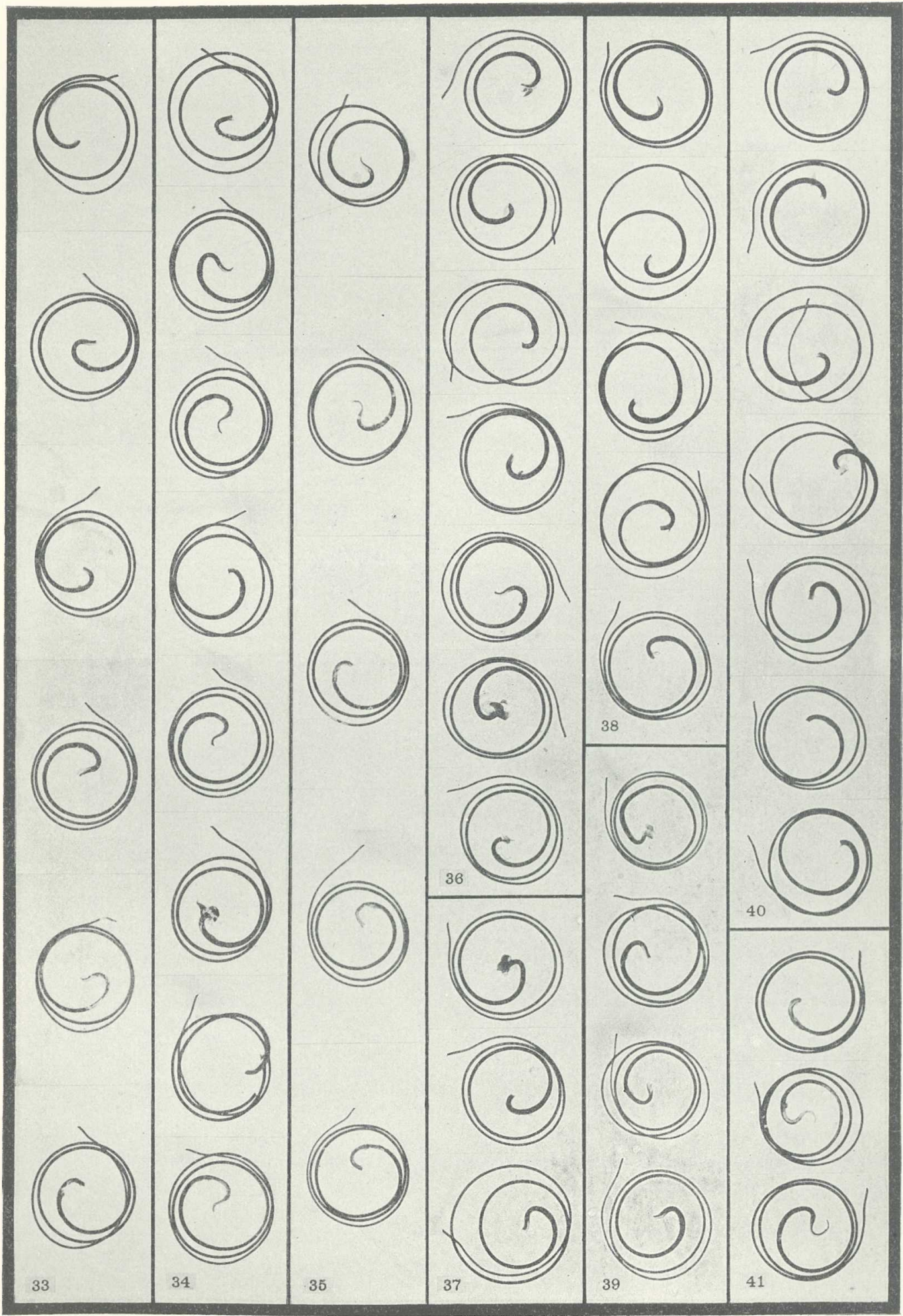




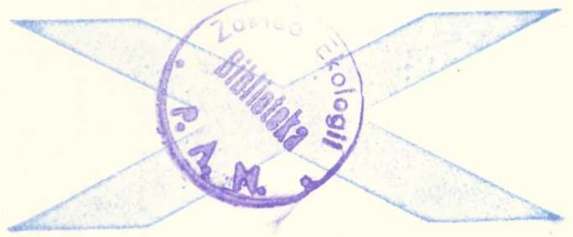

rcin.org.pl 


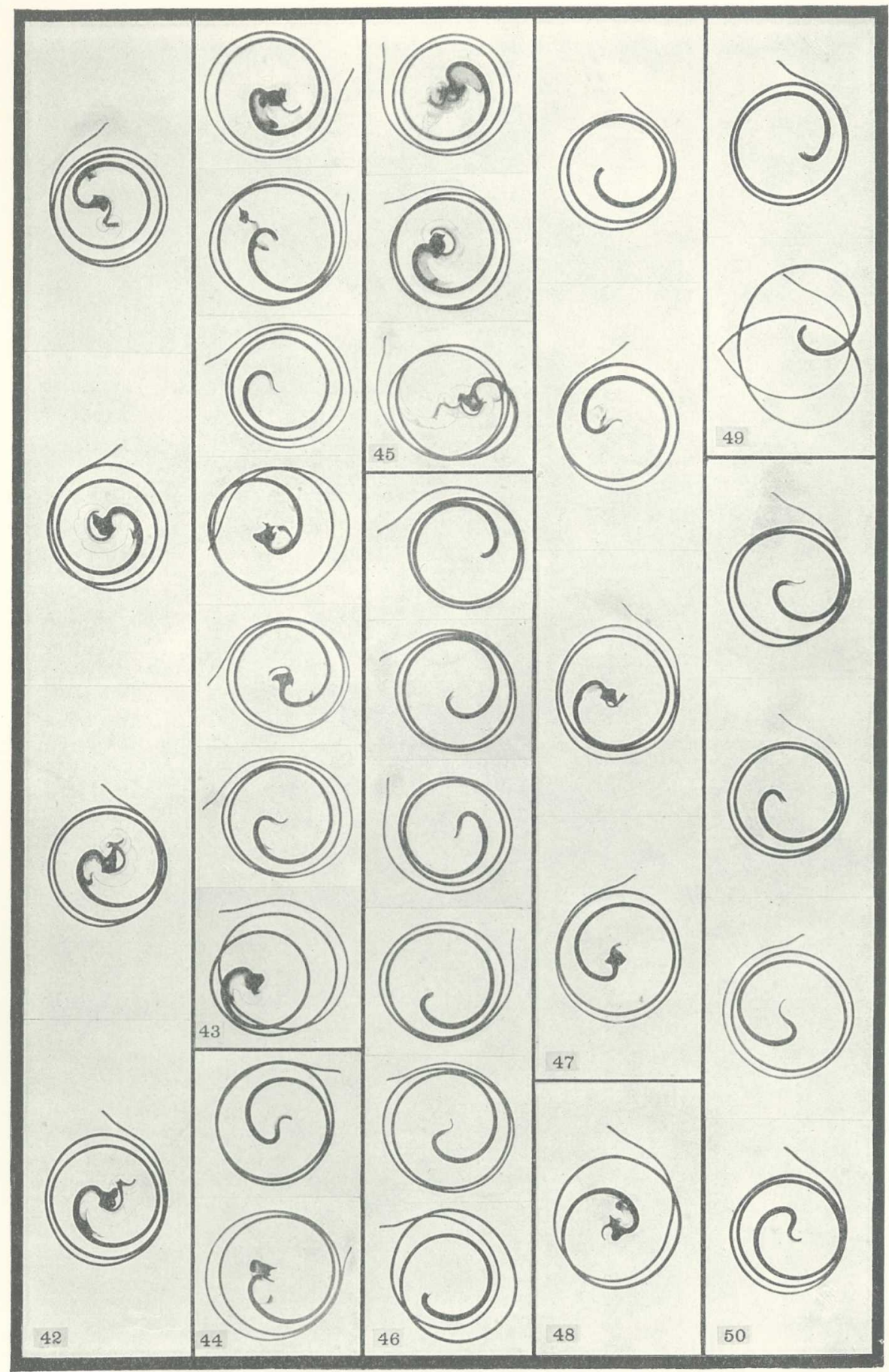

K.F.\& E.C.S., photo.

Andre, Sleigh \& Anglo. Ltd.

INTROMITTENT ORGANS from $F_{2}$ HYBRIDS from E. VARIOLARIUS \& E. SERVUS. 


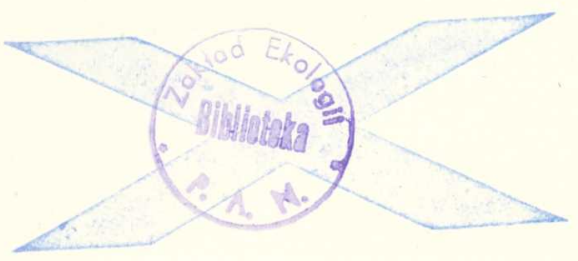

rcin.org.pl 


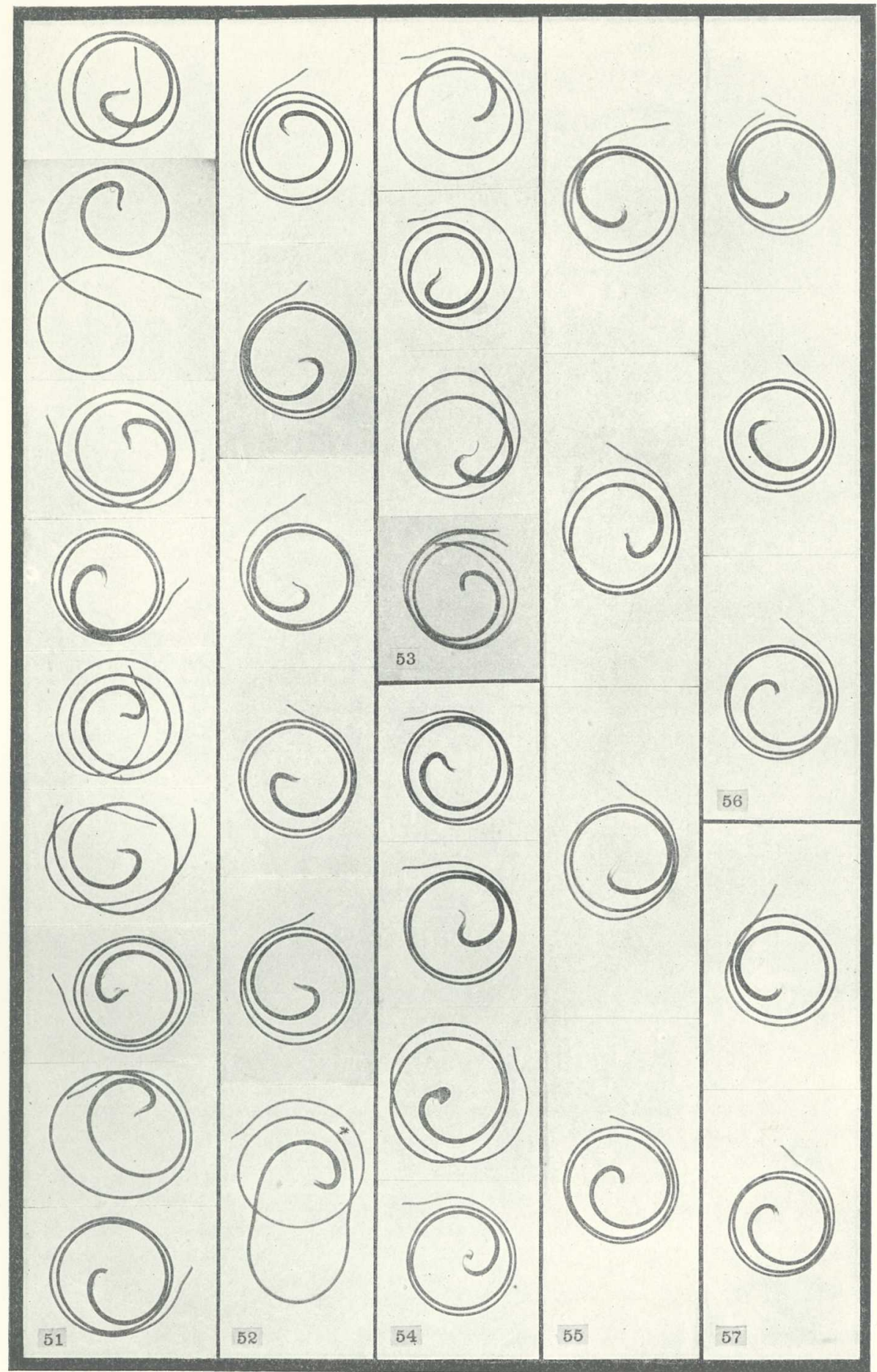

K.F. \& E.C.S., photo.

Andre, Sleigh \& Anglo, Ltd.

INTROMITTENT ORGANS from $F_{2}$ HYBRIDS from

E. VARIOLARIUS \& E. SERVUS. 


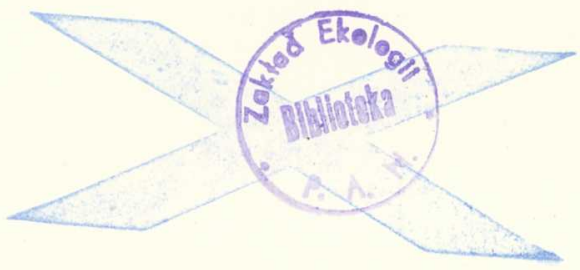

*

rcin.org.pl 


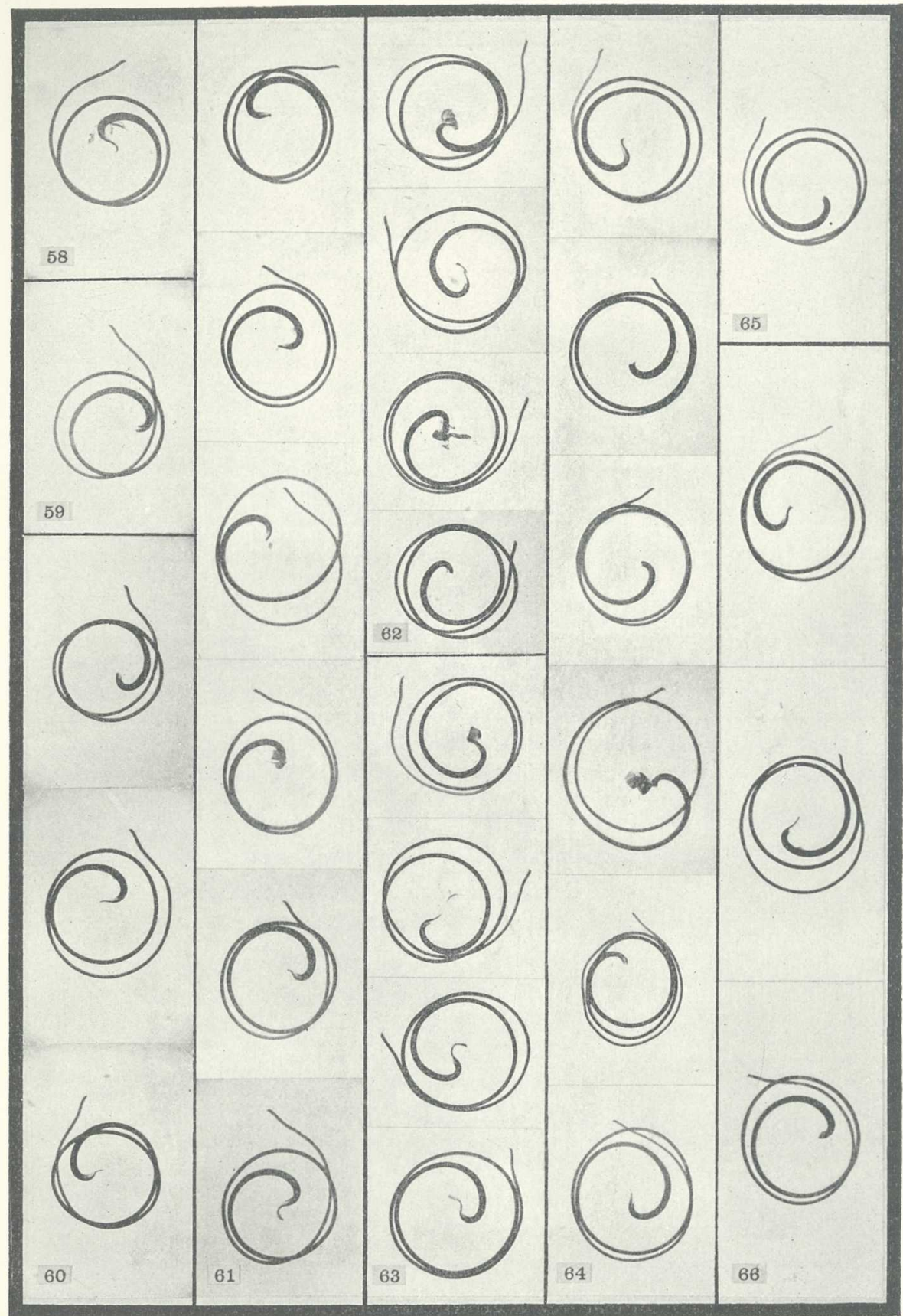

K.F. \& E.C.S., photo.

Andre, Sleigh \& Anglo, Ltd.

INTROMITTENT ORGANS from E. VARIOLARIUS MALES \& MALES from $F_{I}+\times$ E. VARIOLARIUS $ぇ$ 


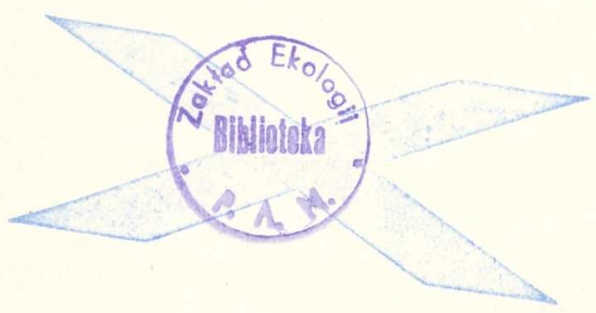

rcin.org.pl 


\section{Plate 47.}

(Cf. Plate 34 of this volume.)

Pното 58. The intromittent organ from the pure rariolarius of photo 58, plate 34. Length of intromittent organ, $94 \mathrm{~mm}$. This pure variolarius male was raised in the laboratory in 19]2, and the same season fertilized both a pure femule variolarius and an $\mathrm{F}_{1}$ hybrid female.

Pнотоs 59-61. Intromittent organs of 10 males from the above-mentioned pair of pure variolariis.

Рното 59. Intromittent organ of the male of photo 59, plate 34. Length of intromittent organ, $94 \mathrm{~mm}$.

Рното 60. Intromittent organs of the three males of photo 60 , plate 34 . Lengths of intromittent organs:-1st (upper), $98 \mathrm{~mm}$. 2nd, $100 \mathrm{~mm}$. $3 \mathrm{rd}, 94 \mathrm{~mm}$.

Рното 61. Intromittent organs of the six males of photo 61, plate 34. Lengths of intromittent organs:--1st (upper), $100 \mathrm{~mm}$. 2nd, $100 \mathrm{~mm}$. 3rd, $100 \mathrm{~mm}$. 4th, $95 \frac{1}{2} \mathrm{~mm}$. 5th, $102 \mathrm{~mm}$. 6 th, $98 \mathrm{~mm}$.

Рнотоs 62-66. Intromittent organs of 18 males from the above-mentioned backcross $\left(\mathrm{F}_{2}\right.$ hybrid $\& \times$ pure variolarius of $)$.

Рното 62. Intromittent organs from the four males of Photo 62, plate 34. Lengths of intromittent organs:-lst (upper), $112 \frac{1}{2} \mathrm{~mm}$. 2nd, $105 \mathrm{~mm}$. $3 \mathrm{rd}, 12-\frac{1}{2} \mathrm{~mm}$. 4 th, $117 \mathrm{~mm}$.

Pното 63. Intromittent organs from the four males of photo 63, plate 34 . Lengths of intromittent organs:-1st (upper), $110 \frac{1}{2} \mathrm{~mm} .2 \mathrm{nd}, 116 \mathrm{~mm}$. $3 \mathrm{rd}, 106 \mathrm{~mm}$. 4 th, $107 \mathrm{~mm}$.

Рното 64. Intromittent organs from the six males of photo 64, plate 34 . Lengths of intromittent organs:-1st (upper), $115 \mathrm{~mm}$. 2nd, $112 \frac{1}{2} \mathrm{~mm}$. 3rd, $122 \frac{1}{2} \mathrm{~mm} . \quad 4 \mathrm{th}, 102 \mathrm{~mm}$. 5th, $119 \mathrm{~mm} . \quad 6$ th, $118 \mathrm{~mm}$.

Рното 65. Intromittent organ from the male of photo 65, plate 34. Length of intromittent organ, $113 \frac{1}{2} \mathrm{~mm}$.

Рното 66. Intromittent organs from the three males of photo 66, plate 34 . Lengths of intromittent organs:-1st (upper), $114 \frac{1}{2} \mathrm{~mm}$. 2nd, $116 \frac{1}{2} \mathrm{~mm}$. $3 \mathrm{rd}, 106 \frac{1}{2} \mathrm{~mm}$.
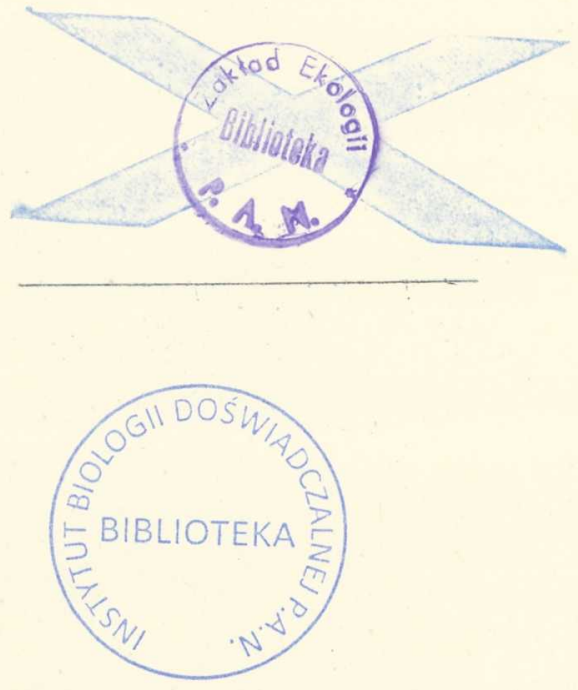
